\title{
New Samoan lavas from Ofu Island reveal a hemispherically heterogeneous high ${ }^{3} \mathrm{He} /{ }^{4} \mathrm{He}$ mantle
}

\author{
Matthew G. Jackson ${ }^{\mathrm{a}, *}$, Mark D. Kurz ${ }^{\mathrm{b}}$, Stanley R. Hart ${ }^{\mathrm{b}}$, Rhea K. Workman ${ }^{\mathrm{c}}$ \\ ${ }^{a}$ Massachusetts Institute of Technology - Woods Hole Oceanographic Institution Joint Program, USA \\ ${ }^{\mathrm{b}}$ Woods Hole Oceanographic Institution, Woods Hole, MA 02543, USA \\ ${ }^{\mathrm{c}}$ School of Ocean and Earth Science and Technology, University of Hawaii, Honolulu, HI 96822, USA
}

Received 16 May 2007; received in revised form 14 September 2007; accepted 17 September 2007

Available online 29 September 2007

Editor: R.W. Carlson

\begin{abstract}
New measurements of high ${ }^{3} \mathrm{He} /{ }^{4} \mathrm{He}$ ratios in Samoan lavas from Ofu Island (19.5-33.8 times atmospheric) extend the known range for ${ }^{3} \mathrm{He} /{ }^{4} \mathrm{He}$ in the southern hemisphere mantle. The Ofu data suggest that the high ${ }^{3} \mathrm{He} /{ }^{4} \mathrm{He}$ mantle component thought to be common to all oceanic hotspots, called FOZO (Focus Zone), is not homogeneous. Sr, Nd and Pb isotopes in Ofu lavas indicate that the Samoan high ${ }^{3} \mathrm{He} /{ }^{4} \mathrm{He}$ component is isotopically distinct from the high ${ }^{3} \mathrm{He} /{ }^{4} \mathrm{He}$ lavas from Hawaii, Iceland and Galapagos. Along with Samoa, the highest ${ }^{3} \mathrm{He} /{ }^{4} \mathrm{He}$ sample from each southern hemisphere high ${ }^{3} \mathrm{He} /{ }^{4} \mathrm{He}$ hotspot exhibits lower ${ }^{143} \mathrm{Nd} /{ }^{144} \mathrm{Nd}$ ratios than their counterparts in the northern hemisphere (excluding lavas erupted in continental, back-arc, and submarine ridge environments). The observation of a large-scale isotopic enrichment (generally higher ${ }^{87} \mathrm{Sr}{ }^{86} \mathrm{Sr}$ and lower ${ }^{143} \mathrm{Nd} /{ }^{144} \mathrm{Nd}$ ) in the FOZO-A (austral) high ${ }^{3} \mathrm{He} /{ }^{4} \mathrm{He}$ mantle compared to the FOZO-B (boreal) high ${ }^{3} \mathrm{He} /{ }^{4} \mathrm{He}$ mantle is similar to the DUPAL anomaly, a globe-encircling feature of isotopic enrichment observed primarily in southern hemisphere ocean island basalts. Additionally, the recent discovery that terrestrial samples have ${ }^{142} \mathrm{Nd} /{ }^{144} \mathrm{Nd}$ ratios higher than chrondrites has potentially important implications for the origin of the FOZO reservoirs, and suggest that the high ${ }^{3} \mathrm{He} /{ }^{4} \mathrm{He}$ mantle has been re-enriched.
\end{abstract}

(C) 2007 Elsevier B.V. All rights reserved.

Keywords: Samoa; FOZO; PHEM; C; 3He/4He; mantle; basalt; geochemistry; DUPAL; hotspot

\section{Introduction}

Oceanic lavas with high ${ }^{3} \mathrm{He} /{ }^{4} \mathrm{He}$ signatures are rare, and derive from ancient reservoirs in the earth's mantle. Volcanically active hotspots with high ${ }^{3} \mathrm{He} /{ }^{4} \mathrm{He}$ lavas, such as Samoa and Hawaii, sample melts of buoyantly upwelling regions of the deep mantle where the high

\footnotetext{
* Corresponding author. Woods Hole Oceanographic Institution, MS \#24, Woods Hole, MA 02543-1525, USA.

E-mail address: mjackson@whoi.edu (M.G. Jackson).
}

${ }^{3} \mathrm{He} /{ }^{4} \mathrm{He}$ reservoir is thought to reside (Kurz et al., 1982; Hart et al., 1992; Class and Goldstein, 2005). Consequently, ocean island basalts (OIBs) erupted at hotspots provide a unique tool for probing the composition and history of the deep mantle. Radiogenic isotopes in OIBs are commonly used as tracers for the various mantle components revealed at hotspots, and show a diverse range of compositions, or endmembers, including DMM (depleted mid-ocean ridge basalt [MORB] mantle), HIMU (high ' $\mu$ ', or ${ }^{238} \mathrm{U} /{ }^{204} \mathrm{~Pb}$ mantle), EM1 and EM2 (enriched mantle 1 and 2) (Zindler and Hart, 1986). 
Emerging from this taxonomic diversity, a unifying theory in mantle geochemistry maintains that a single mantle component exists that is common to all hotspots (Hart et al., 1992): Mixing arrays from individual ocean islands originate near the mantle endmembers in various radiogenic isotope spaces and converge on a region characterized by depleted isotope ratios that is distinct from normal MORB (Hart et al., 1992). Lavas plotting in this region of convergence often exhibit elevated ${ }^{3} \mathrm{He} /{ }^{4} \mathrm{He}$ ratios, and are suggested to sample a component in the mantle common to all hotspots. Variably called FOZO (Hart et al., 1992), PHEM (Primitive Helium Mantle; Farley et al., 1992), or C (Common; Hanan and Graham, 1996), the high ${ }^{3} \mathrm{He} /{ }^{4} \mathrm{He}$ common component is thought to be a relatively less degassed region of the (lower?) mantle (Kurz et al., 1982; Class and Goldstein, 2005).

New geochemical data from the Samoan hotspot are not entirely consistent with this view of the mantle. The new ${ }^{3} \mathrm{He} /{ }^{4} \mathrm{He}$ ratios (up to $33.8 \pm 0.2 \mathrm{Ra}$, ratio to atmosphere) from the Samoan Island of Ofu are the highest yet recorded in the southern hemisphere, and are significantly higher than ${ }^{3} \mathrm{He} /{ }^{4} \mathrm{He}$ ratios previously measured $(25.8 \mathrm{Ra})$ in Samoan basalts and xenoliths (Farley et al., 1992; Poreda and Farley, 1992; Workman et al., 2004). The new helium isotope data from Samoa extend the range of observed ${ }^{3} \mathrm{He} /{ }^{4} \mathrm{He}$ up to values comparable to those found in Hawaii (32.3 Ra; Kurz et al., 1982), Iceland (37.7 Ra; Hilton et al., 1999) and the Galapagos (30.3 Ra; Kurz and Geist, 1999; Saal et al., 2007), referred to here as HIG. The Ofu lavas are isotopically more enriched (higher ${ }^{87} \mathrm{Sr} /{ }^{86} \mathrm{Sr}$ and lower ${ }^{143} \mathrm{Nd} /{ }^{144} \mathrm{Nd}$ ) than the high ${ }^{3} \mathrm{He} /{ }^{4} \mathrm{He}$ samples from HIG and exhibit elevated incompatible trace element concentrations. Due to this isotopic and trace element enrichment relative to HIG lavas, the new data from Samoan high ${ }^{3} \mathrm{He} /{ }^{4} \mathrm{He}$ lavas are inconsistent with recent models that describe the evolution of the high ${ }^{3} \mathrm{He} /{ }^{4} \mathrm{He}$ mantle, and the Ofu data suggest that the high ${ }^{3} \mathrm{He} /{ }^{4} \mathrm{He}$ mantle domain is isotopically heterogeneous.

\section{Methods and results}

\subsection{Sample location and state of preservation}

Ofu Island is located in the eastern province of the Samoan archipelago, an age-progressive hotspot track (Hart et al., 2004; Koppers et al., submitted for publication) located just north of the northern terminus of the Tonga subduction zone. The samples were collected at various locations on the perimeter of Ofu and Olosega islands (Ofu hereafter; sample location map is available in the supplementary data in the Appendix). Tholeiitic lavas in Samoa are rare (Natland, 1980; Workman et al., 2004), and with the exception of a cumulate (OFU-04-14) and a gabbro (OFU-04-17), the Ofu lavas presented in this study are alkali basalts (Table 1). The Ofu samples are generally quite fresh. With the exception of sample OFU-04-12, which has a $\mathrm{Th} / \mathrm{U}$ ratio of 4.8 (and may indicate U-loss during subaerial weathering), the range of $\mathrm{Th} / \mathrm{U}$ ratios in the Ofu sample suite is $4.0-4.4$. The $\mathrm{Ba} / \mathrm{Rb}$ ratios for Ofu samples $(9.1 \pm 1.1$ at $1 \sigma)$ are similar to the values for young Samoan basalts reported previously (Workman et al., 2004), and somewhat lower than the canonical value of $\sim 12$ for fresh OIB lavas (Hofmann and White, 1983). Excluding the cumulate sample OFU-04-14, which has a $\mathrm{Rb} / \mathrm{Cs}$ ratio of 280 , the range of $\mathrm{Rb} / \mathrm{Cs}$ values from the Ofu samples (from 73 to 137) is close to the canonical range of 85-95 (Hofmann and White, 1983). These weathering proxies indicate that elements equally or less mobile than $\mathrm{U}, \mathrm{Rb}$ and $\mathrm{Cs}$ yield useful petrogenetic information.

\subsection{He, $\mathrm{Sr}, \mathrm{Nd}$ and $\mathrm{Pb}$ isotopes in Ofu lavas}

New ${ }^{3} \mathrm{He} /{ }^{4} \mathrm{He}$ values (19.5 to $33.8 \mathrm{Ra}$ ) were measured at Woods Hole Oceanographic Institution on olivine and clinopyroxene (cpx) phenocrysts separated from 12 hand samples (Table 1). Measurements were made by crushing and fusion in vacuo, following the protocol reported in (Kurz et al., 2004). The sample with the highest ${ }^{3} \mathrm{He} /{ }^{4} \mathrm{He}$ value, OFU-04-06, was taken from an ankaramite dike exposed at $2 \mathrm{~m}$ depth in a recent road cut. Olivines from this sample are relatively gas rich $\left(67.5 \times 10^{-9} \mathrm{~cm}^{3}\right.$ STP $\mathrm{g}^{-1}$, the sum of crushing and fusion) and yielded similar ${ }^{3} \mathrm{He} /{ }^{4} \mathrm{He}$ ratios on two separate crushes of the same olivine separate (OFU-04-06cr1 followed by OFU-04-06cr2). Following the crushing experiments, a fusion extraction of the resulting olivine powder (OFU-04-06fus) yielded lower ${ }^{3} \mathrm{He} /{ }^{4} \mathrm{He}$, indicating the presence of ingrown radiogenic helium, probably implanted from the Th and U-rich matrix. Two different olivine populations (lighter and darker olivines) separated from sample OFU-04-06 yielded similar ${ }^{3} \mathrm{He} /{ }^{4} \mathrm{He}$ ratios (33.4 and 33.6 Ra). These fusion and crushing experiments, coupled with sampling depths, preclude the influence of cosmogenic helium for this important sample. The lava with the second highest ${ }^{3} \mathrm{He} /{ }^{4} \mathrm{He}$ value measured by crushing-sample OFU-0415 -also yielded lower ${ }^{3} \mathrm{He} /{ }^{4} \mathrm{He}$ ratios upon fusion (OFU-04-15fus) of the crushed olivine powder. Additionally, crushing experiments of sample OFU-04-03 (OFU-04-03cr1 followed by OFU-04-03cr2) yielded 
Table 1

Isotopic and (selected) trace element analyses of Ofu and Moorea lavas

\begin{tabular}{|c|c|c|c|c|c|c|c|c|c|c|c|c|c|c|c|c|c|c|}
\hline Sample & $\begin{array}{l}\text { Phase analyzed } \\
\text { for helium }\end{array}$ & Rock type & $\begin{array}{l}\text { Geological } \\
\text { formation }\end{array}$ & $\begin{array}{l}{ }^{4} \mathrm{He} \\
\left(10^{-9} \mathrm{~cm}^{3} \text { STP } \mathrm{g}^{-1}\right)\end{array}$ & $\begin{array}{l}{ }^{3} \mathrm{He} /{ }^{4} \mathrm{He} \\
\left(\mathrm{R} / \mathrm{R}_{\mathrm{a}}\right)\end{array}$ & $1 \sigma$ & ${ }^{87} \mathrm{Sr} /{ }^{86} \mathrm{Sr}$ & ${ }^{143} \mathrm{Nd} /{ }^{144} \mathrm{Nd}$ & ${ }^{206} \mathrm{~Pb} /{ }^{204} \mathrm{~Pb}$ & ${ }^{207} \mathrm{~Pb} /{ }^{204} \mathrm{~Pb}$ & ${ }^{208} \mathrm{~Pb} /{ }^{204} \mathrm{~Pb}$ & Th & $\mathrm{Sr}$ & $\mathrm{Th} / \mathrm{U}$ & $\mathrm{Ba} / \mathrm{Rb}$ & $\mathrm{Rb} / \mathrm{Cs}$ & $\mathrm{Ba} / \mathrm{Nb}$ & $\mathrm{Pb} / \mathrm{Pb}^{*}$ \\
\hline OFU-04-02 & Olivine & Ankaramite & Dike & 38.6 & 24.6 & 0.1 & NA & NA & NA & NA & NA & NA & NA & NA & NA & NA & NA & NA \\
\hline OFU-04-03cr1 & Olivine & Ankaramite & Dike & 119 & 24.0 & 0.1 & 0.704756 & 0.512811 & 19.257 & 15.591 & 39.418 & 3.26 & 390 & 4.29 & 7.19 & 117.1 & 5.3 & 0.44 \\
\hline OFU-04-03cr2 & Olivine & Ankaramite & Dike & 11.5 & 23.9 & 0.2 & $"$ & $"$ & $"$ & $"$ & $"$ & $"$ & $"$ & $"$ & $"$ & $"$ & $"$ & $"$ \\
\hline OFU-04-05 & Olivine & Ankaramite & Dike & 70.8 & 24.4 & 0.1 & 0.704793 & 0.512814 & 19.254 & 15.589 & 39.412 & 4.24 & 546 & 4.26 & 7.81 & 136.7 & 5.6 & 0.43 \\
\hline OFU-04-06cr1 & Olivine & Ankaramite & Dike & 44.0 & 33.7 & 0.2 & 0.704584 & 0.512827 & 19.189 & 15.571 & 39.202 & 3.96 & 599 & 3.99 & 9.71 & 77.7 & 4.9 & 0.42 \\
\hline OFU-04-06cr2 & Olivine & Ankaramite & Dike & 5.0 & 33.8 & 0.2 & $"$ & $"$ & $"$ & $"$ & $"$ & $"$ & $"$ & $"$ & $"$ & $"$ & $"$ & $"$ \\
\hline OFU-04-06 fus & Olivine & Ankaramite & Dike & 18.5 & 27.0 & 0.1 & $"$ & $"$ & $"$ & $"$ & $"$ & $"$ & $"$ & $"$ & $"$ & $”$ & $"$ & $"$ \\
\hline $\begin{array}{l}\text { OFU-04-06 } \\
\quad \text { (light olivines) }\end{array}$ & Olivine & Ankaramite & Dike & 27.3 & 33.4 & 0.2 & $"$ & $"$ & $"$ & $"$ & $"$ & $"$ & $"$ & $"$ & $"$ & $"$ & $"$ & $"$ \\
\hline $\begin{array}{l}\text { OFU-04-06 } \\
\quad \text { (dark olives) }\end{array}$ & Olivine & Ankaramite & Dike & 40.0 & 33.6 & 0.1 & $"$ & $"$ & $"$ & $"$ & $"$ & $"$ & $"$ & $"$ & $"$ & $"$ & $"$ & $"$ \\
\hline OFU-04-06 ${ }^{\mathrm{a}}$ & cpx & Ankaramite & Dike & 0.2 & 26.1 & 3.4 & $"$ & $"$ & $"$ & $"$ & $"$ & $"$ & $"$ & $"$ & $"$ & $"$ & $"$ & $"$ \\
\hline OFU-04-07 & none & Trachybasalt & Dike & NA & NA & NA & 0.704623 & 0.512814 & 19.177 & 15.582 & 39.268 & 5.24 & 767 & 4.04 & 9.59 & 122.0 & 5.0 & 0.39 \\
\hline OFU-04-08 & Olivine & Ankaramite & Dike & 4.5 & 21.3 & 0.3 & 0.704703 & 0.512802 & 19.207 & 15.586 & 39.291 & 4.06 & 573 & 4.11 & 8.78 & 77.5 & 4.7 & 0.42 \\
\hline OFU-04-09 & Olivine & Ankaramite & Flow & 3.2 & 25.6 & 0.5 & 0.704538 & 0.512835 & 19.165 & 15.577 & 39.208 & 3.25 & 503 & 4.03 & 10.20 & 131.6 & 5.4 & 0.46 \\
\hline OFU-04-10 & Olivine & Alkali Basalt & Flow & 8.0 & 22.0 & 0.2 & $"$ & $"$ & $"$ & $"$ & $”$ & $"$ & $"$ & $"$ & $"$ & $"$ & $"$ & $"$ \\
\hline OFU-04-10 & cpx & Alkali Basalt & Flow & 1.0 & 19.7 & 0.6 & 0.704648 & 0.512815 & 19.187 & 15.585 & 39.261 & 3.65 & 495 & 4.39 & 10.79 & 73.0 & 5.8 & 0.43 \\
\hline OFU-04-11 & None & Trachybasalt & Flow & NA & NA & NA & 0.704635 & 0.512804 & 19.184 & 15.594 & 39.299 & 6.60 & 929 & 4.30 & 9.09 & 108.0 & 5.3 & 0.45 \\
\hline OFU-04-12 & Olivine & Alkali Basalt & Flow & 3.5 & 21.2 & 0.3 & 0.704795 & 0.512800 & 19.202 & 15.594 & 39.403 & 3.29 & 331 & 4.78 & 10.36 & 118.3 & 6.2 & 0.42 \\
\hline OFU-04-13 & None & Hawaiite & Flow & NA & NA & NA & 0.704625 & 0.512816 & 19.176 & 15.581 & 39.264 & 5.02 & 723 & 4.07 & 9.09 & 99.2 & 4.8 & 0.40 \\
\hline OFU-04-14 & Olivine & Cumulate & Boulder & 4.5 & 25.0 & 0.2 & 0.704517 & 0.512819 & 19.126 & 15.584 & 39.164 & 2.95 & 292 & 4.39 & 9.88 & 280.2 & 4.9 & 0.37 \\
\hline OFU-04-15 & Olivine & Ankaramite & Boulder & 14.3 & 29.6 & 0.2 & 0.704559 & 0.512822 & 19.141 & 15.580 & 39.169 & 3.89 & 601 & 4.02 & 9.28 & 88.0 & 4.8 & 0.43 \\
\hline OFU-04-15 fus & Olivine & Ankaramite & Boulder & 3.2 & 21.2 & 0.2 & $"$ & $"$ & $"$ & $"$ & $"$ & $"$ & $"$ & $"$ & $"$ & $”$ & $"$ & $"$ \\
\hline OFU-04-16 & $\operatorname{cpx}$ & Alkali Basalt & Boulder & 0.2 & 19 & 1 & 0.704438 & 0.512834 & 19.216 & 15.587 & 39.276 & 3.54 & 639 & 3.96 & 8.60 & 129.6 & 5.3 & 0.46 \\
\hline OFU-04-17 & Olivine & Gabbro & Boulder & 1.0 & 26.4 & 0.4 & 0.704498 & 0.512844 & 19.160 & 15.576 & 39.173 & 2.18 & 310 & 4.14 & 7.30 & 118.2 & 5.1 & 0.41 \\
\hline $\begin{array}{l}\text { MO01-01 } \\
\text { (Moorea) }^{\text {b }}\end{array}$ & Olivine & Ankaramite & NA & 1.3 & 17.0 & 1.6 & 0.704621 & 0.512774 & 19.216 & 15.603 & 38.933 & 2.11 & 381 & 3.75 & 11.14 & 270.4 & 8.5 & 0.50 \\
\hline
\end{tabular}

Samples were collected at Ofu Island, American Samoa in August of 2004 . All ${ }^{3} \mathrm{He} /{ }^{4} \mathrm{He}$ ratios are reported relative to atmospheric $(\mathrm{R} / \mathrm{Ra})$ using an atmospheric value of $1.384 \times 10^{-6}$. The $\mathrm{Sr}$, Nd, and $\mathrm{Pb}$ chemistry, mass spectrometry and associated measurement precision are reported in Hart and Blusztajn (2006). Sr, Nd and Pb-isotope analyses were performed on leached whole-rock powders. Trace elements analyses were performed on unleached whole-rock powders by ICP at the Washington State University GeoAnalytical Lab.

Errors associated with trace element analyses can be found in Jackson et al. (2007). Only two samples (OFU-04-06 fus and OFU-04-15 fus) were fused for helium isotope measurement. All other helium measurements were made by crushing. When an olivine sample was crushed and measured more than once, the crush experiment is labeled as "cr1 or cr2".

${ }^{a}$ Required a blank correction of $46 \%$ due to low gas concentrations. The ${ }^{3} \mathrm{He} /{ }^{4} \mathrm{He}$ ratio on this clinopyroxene measurement is similar to the olivine crush values at the $2 \sigma$ level.

b The sample is from Moorea in the Societies island chain, a hotspot that exhibits EM2 affinities. Helium isotope data were previously published on Societies sample MO01-01 in Hanyu and Kaneoka (1997). Sr, Nd and Pb isotopes by same method as Ofu rocks. 
reproducible results. The reproducibility of the measurements for Ofu samples, the relatively high helium concentrations, the absence of higher ${ }^{3} \mathrm{He} /{ }^{4} \mathrm{He}$ ratios on melting, and shielding of many of the samples all indicate that cosmogenic ${ }^{3} \mathrm{He}$ is not a factor in generating the remarkably high ${ }^{3} \mathrm{He} /{ }^{4} \mathrm{He}$ ratios.

$\mathrm{The} \mathrm{Sr}, \mathrm{Nd}$, and $\mathrm{Pb}$ chemistry, mass spectrometry, associated measurement precision and standard normalizations are reported in Hart and Blusztajn (2006) and references therein. Basalt $\mathrm{Sr}, \mathrm{Nd}$ and $\mathrm{Pb}$-isotope analyses were performed on the same powder following $1 \mathrm{~h}$ of leaching in $6.2 \mathrm{~N} \mathrm{HCl}$ at $100{ }^{\circ} \mathrm{C}$. $\mathrm{Sr}$ and $\mathrm{Nd}$ chemistry
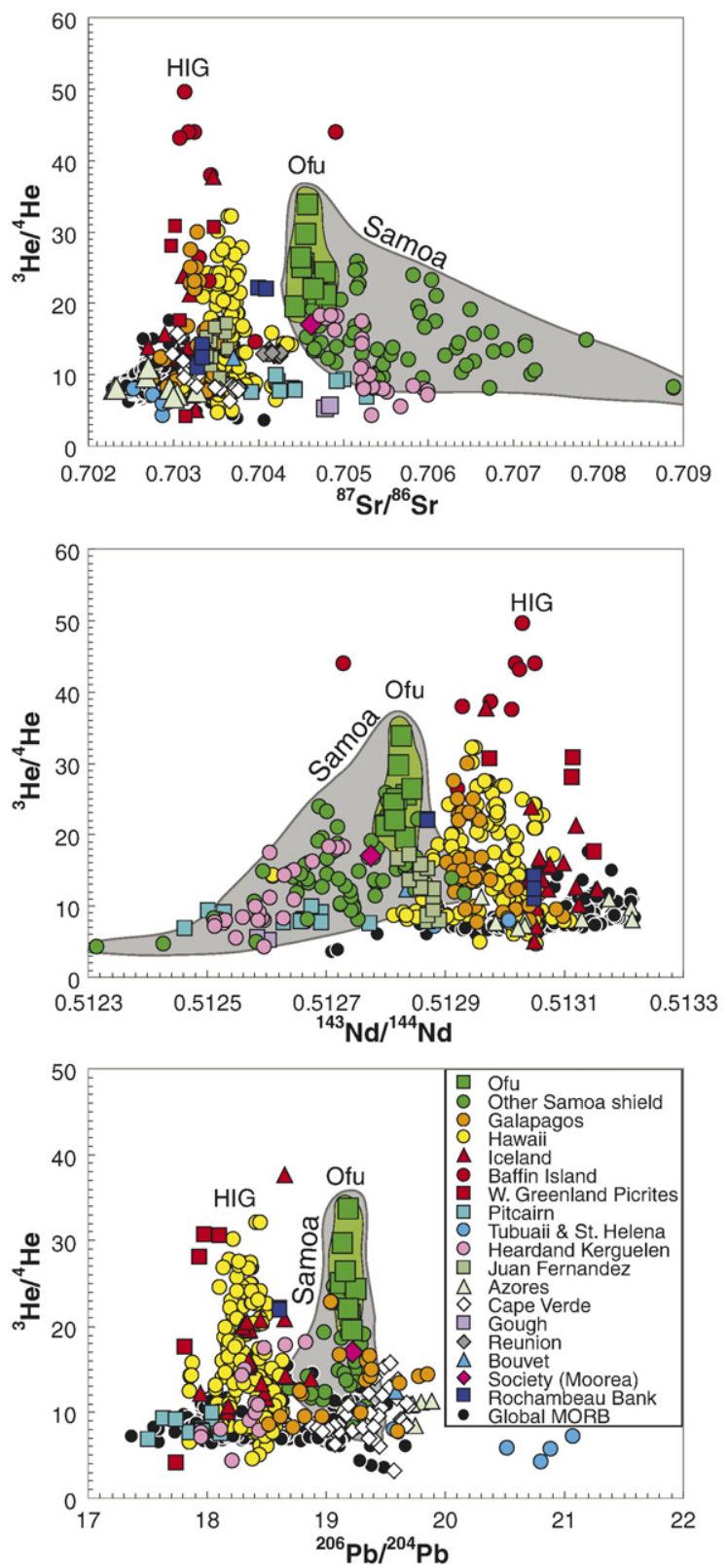

was done with conventional ion chromatography using DOWEX 50 cation resin and HDEHP-treated teflon for $\mathrm{Nd}$ separation (Taras and Hart, 1987). An $\mathrm{HBr}-\mathrm{HNO}_{3}$ procedure (Galer, 1986; Abouchami et al., 1999) was used for $\mathrm{Pb}$ chemistry, with a single column pass. $\mathrm{Sr}, \mathrm{Nd}$, and $\mathrm{Pb}$-isotope analyses were done on the NEPTUNE multi-collector ICP-MS at WHOI. Internal precision is 5-10 ppm $(2 \sigma)$ for $\mathrm{Sr}$ and $\mathrm{Nd}$-isotope measurements. Adjusting to 0.710240 (SRM987 $\mathrm{Sr}$ standard) and 0.511847 (La Jolla Nd standard) gives an estimated external precision for $\mathrm{Sr}$ and $\mathrm{Nd}$ of $15-25 \mathrm{ppm}(2 \sigma)$. The internal precision for $\mathrm{Pb}$-isotope ratios is better than 15-30 ppm, and using SRM997 $\mathrm{Tl}$ as an internal standard, the external reproducibility following full chemistry ranges from $\sim 20 \mathrm{ppm}(2 \sigma)$ for ${ }^{207} \mathrm{~Pb} /{ }^{206} \mathrm{~Pb}$ to $\sim 120 \mathrm{ppm}(2 \sigma)$ for ${ }^{208} \mathrm{~Pb} /{ }^{204} \mathrm{~Pb}$ (Hart and Blusztajn, 2006). $\mathrm{Pb}$-isotope ratios are adjusted to the SRM 981 values of Todt et al. (1996).

Ofu lavas exhibit slight variations in the radiogenic isotope ratios of ${ }^{87} \mathrm{Sr} /{ }^{86} \mathrm{Sr}(0.704438-0.704795)$, ${ }^{143} \mathrm{Nd} /{ }^{144} \mathrm{Nd}(0.512800$ to 0.512844$)$ and ${ }^{206} \mathrm{~Pb} /{ }^{204} \mathrm{~Pb}$ (19.126 to 19.257 ) (Fig. 1 and Table 1). Together with Ofu, data from Samoan lavas in general define a wedgelike shape in ${ }^{3} \mathrm{He} /{ }^{4} \mathrm{He}-{ }^{87} \mathrm{Sr} /{ }^{86} \mathrm{Sr}$ isotope space: lavas with the highest (more enriched) ${ }^{87} \mathrm{Sr} /{ }^{86} \mathrm{Sr}$ ratios exhibit low ${ }^{3} \mathrm{He} /{ }^{4} \mathrm{He}$ ratios and samples with the least radiogenic ${ }^{87} \mathrm{Sr} /{ }^{86} \mathrm{Sr}$ ratios, found primarily at Ofu, are associated with the highest ${ }^{3} \mathrm{He} /{ }^{4} \mathrm{He}$ ratios (Fig. 1). Similarly, Samoan lavas with the most enriched (lowest) ${ }^{143} \mathrm{Nd} /$ ${ }^{144} \mathrm{Nd}$ have low ${ }^{3} \mathrm{He} /{ }^{4} \mathrm{He}$ ratios. However, $\mathrm{Nd}$ and $\mathrm{Pb}$ isotopes measured in Ofu lavas do not define end-member values for Samoa, but instead fall toward the upper end found in the hotspot.

In order to further constrain the nature of elevated ${ }^{3} \mathrm{He} /{ }^{4} \mathrm{He}$ lavas associated with EM2 hotspots, we present $\mathrm{Sr}, \mathrm{Nd}$ and $\mathrm{Pb}$ isotopes for a high ${ }^{3} \mathrm{He} /{ }^{4} \mathrm{He}$ sample from

Fig. 1. The new Ofu data indicate that the Samoan high ${ }^{3} \mathrm{He} /{ }^{4} \mathrm{He}$ lavas have more enriched ${ }^{87} \mathrm{Sr} /{ }^{86} \mathrm{Sr}$ and ${ }^{143} \mathrm{Nd} /{ }^{144} \mathrm{Nd}$ than the highest ${ }^{3} \mathrm{He} /{ }^{4} \mathrm{He}$ lavas from Hawaii, Iceland and Galapagos (abbreviated HIG). The field of Samoan shield basalts is shaded grey, and the field of Samoan lavas from Ofu Island is shaded green (see Table 1). HIG lavas trend to a more isotopically depleted high ${ }^{3} \mathrm{He} /{ }^{4} \mathrm{He}$ component than lavas from Ofu. A single sample from Baffin Island is an exception to the $\mathrm{Sr}$ and Ndisotope separation between the Ofu and HIG lavas, but was indicated by Stuart et al. (2003) to be crustally contaminated. Data sources are summarized in Graham (2002) or noted in Table 2. In the isotope projections shown in this figure, the separation between the highest ${ }^{3} \mathrm{He} /{ }^{4} \mathrm{He}$ samples from the northern and southern hemisphere high ${ }^{3} \mathrm{He} /{ }^{4} \mathrm{He}$ hotspots is not perfect. For example, the Pb-isotopes of the highest ${ }^{3} \mathrm{He} /{ }^{4} \mathrm{He}$ lavas from Samoa and the Galapagos overlap. However, the isotopic and hemispheric separation of FOZO-A and FOZO-B samples (Table 2) is observed in the isotope projections shown in Fig. 2. 
a.

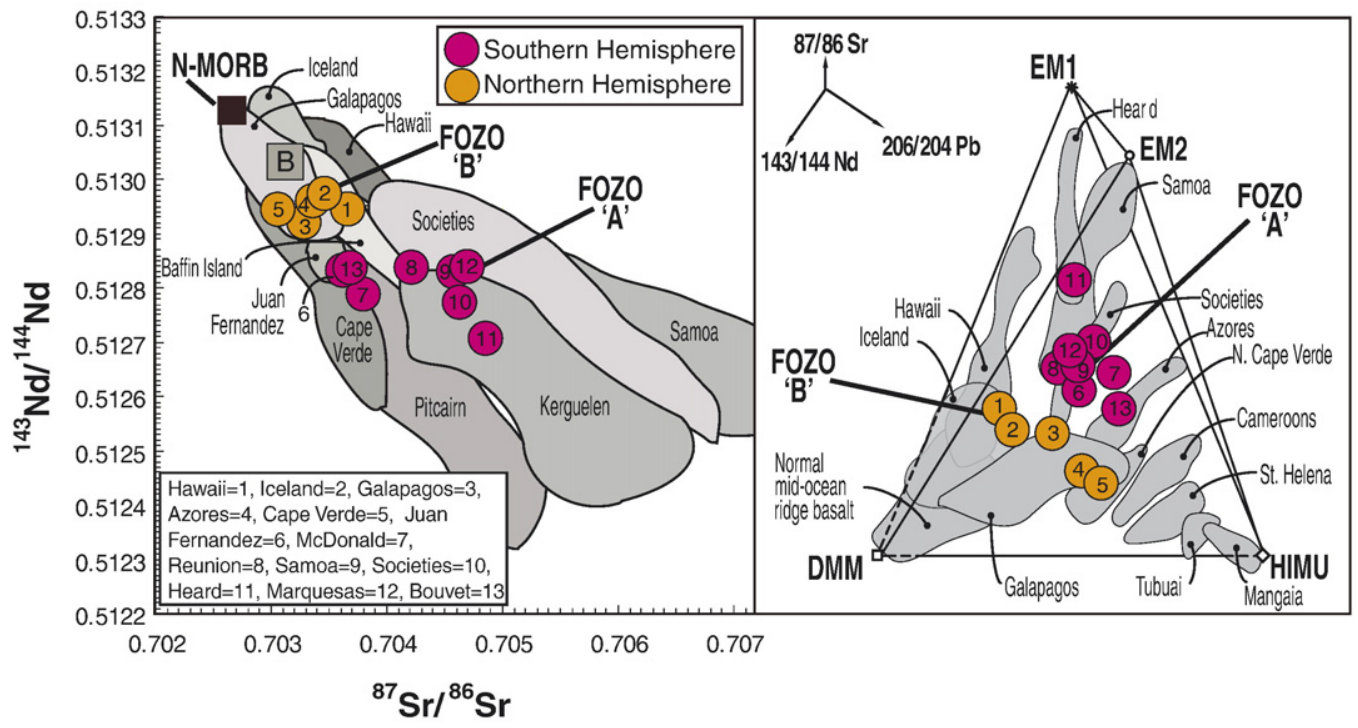

C.

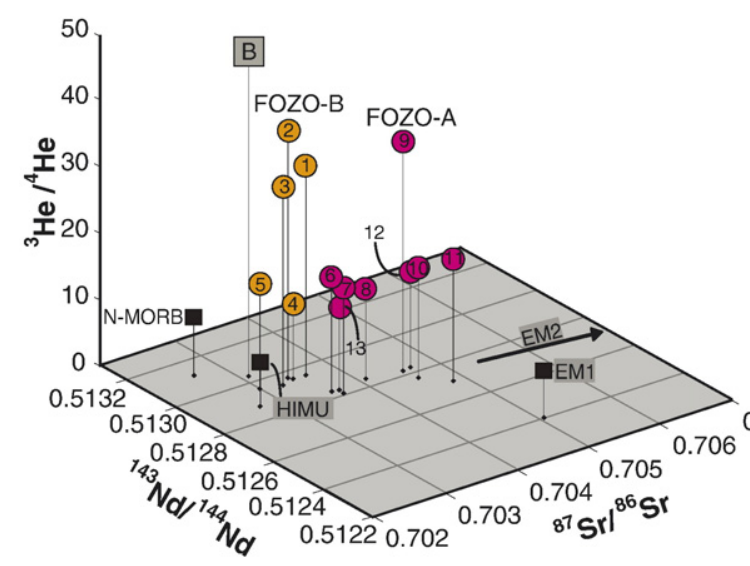

b.

d.

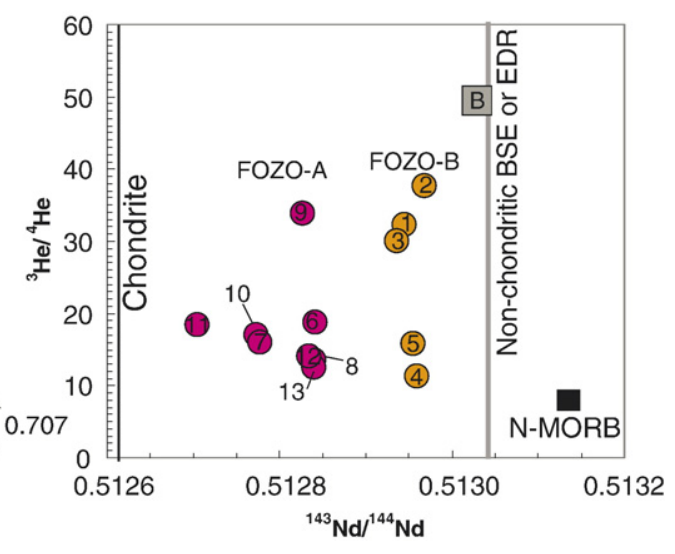

Fig. 2. The highest ${ }^{3} \mathrm{He} /{ }^{4} \mathrm{He}$ lavas from northern hemisphere (FOZO-B) hotspots separate from the highest ${ }^{3} \mathrm{He} /{ }^{4} \mathrm{He}$ samples from southern hemisphere (FOZO-A) hotspots in a.) ${ }^{87} \mathrm{Sr} /{ }^{86} \mathrm{Sr}-{ }^{143} \mathrm{Nd} /{ }^{144} \mathrm{Nd}$ space, b.) the mantle tetrahedron, c.) a "helium balloon" pinplot showing ${ }^{87} \mathrm{Sr} /{ }^{86} \mathrm{Sr}-$ ${ }^{143} \mathrm{Nd} /{ }^{144} \mathrm{Nd}-{ }^{3} \mathrm{He} /{ }^{4} \mathrm{He}$, and d.) ${ }^{143} \mathrm{Nd} /{ }^{144} \mathrm{Nd}-{ }^{3} \mathrm{He} /{ }^{4} \mathrm{He}$ isotope spaces. The criteria for selecting high ${ }^{3} \mathrm{He} /{ }^{4} \mathrm{He}$ lavas with $\mathrm{Sr}-\mathrm{Nd}-\mathrm{Pb}$ isotopes most representative of the OIB mantle are described in Table 2 and Sections 3 and 4.1 of the text. The EDR and the non-chondritic BSE are described in Fig. 6. Although the Baffin Island lava (square marked with a "B") is erupted in a continental setting, and is thus excluded from the compilation of high ${ }^{3} \mathrm{He} /{ }^{4} \mathrm{He}$ lavas (see Table 2), it hosts the highest magmatic ${ }^{3} \mathrm{He} /{ }^{4} \mathrm{He}$ on record and is included in the figure for reference. The highest ${ }^{3} \mathrm{He} /{ }^{4} \mathrm{He}$ lavas from each hotspot (and the high ${ }^{3} \mathrm{He} /{ }^{4} \mathrm{He}$ Baffin Island lava) are significantly more enriched than the N-MORB composition from Su (1986), consistent with earlier observations (Hart et al., 1992). Compared to other southern hemisphere high ${ }^{3} \mathrm{He} /{ }^{4} \mathrm{He}$ lavas, Samoan high ${ }^{3} \mathrm{He} /{ }^{4} \mathrm{He}$ lavas do not exhibit anomalous $\mathrm{Sr}, \mathrm{Nd}$ and $\mathrm{Pb}$ isotopes.

Moorea island in the Societies hotspot. The high ${ }^{3} \mathrm{He} /{ }^{4} \mathrm{He}$ sample from Moorea, MO01-01, has a ${ }^{3} \mathrm{He} /{ }^{4} \mathrm{He}$ ratio of 17.0 Ra (Hanyu and Kaneoka, 1997), and has Sr, Nd and $\mathrm{Pb}$-isotope ratios similar to Ofu basalts (Table 1).

\section{Ofu in a global context}

The ${ }^{87} \mathrm{Sr} /{ }^{86} \mathrm{Sr}$ and ${ }^{143} \mathrm{Nd} /{ }^{144} \mathrm{Nd}$ compositions of Ofu lavas show that the high ${ }^{3} \mathrm{He} /{ }^{4} \mathrm{He}$ reservoir sampled by the
Samoan hotspot is more enriched than the high ${ }^{3} \mathrm{He} /{ }^{4} \mathrm{He}$ reservoir sampled by HIG lavas. Data in Fig. 1 show a clear "valley" between the highest ${ }^{3} \mathrm{He} /{ }^{4} \mathrm{He}$ Samoan and HIG lavas; samples with ${ }^{3} \mathrm{He} /{ }^{4} \mathrm{He}$ greater than $\sim 22 \mathrm{Ra}$ have not been found in this gap. The Ofu samples have ${ }^{87} \mathrm{Sr} /{ }^{86} \mathrm{Sr}$ ratios greater than 0.7044 , while the high ${ }^{3} \mathrm{He} /{ }^{4} \mathrm{He} \mathrm{HIG}$ lavas have ${ }^{87} \mathrm{Sr} /{ }^{86} \mathrm{Sr}$ less than 0.7038 ; a single Baffin Island sample, which is considered by Stuart et al. (2003) to be affected by contamination from 
Table 2

Summary of the radiogenic isotope data for the highest ${ }^{3} \mathrm{He} /{ }^{4} \mathrm{He}$ samples used to define FOZO-A and FOZO-B

\begin{tabular}{|c|c|c|c|c|c|c|c|c|c|}
\hline Hotspot & $\begin{array}{l}\text { Island/ } \\
\text { seamount/ } \\
\text { region }\end{array}$ & $\begin{array}{l}\text { ID of sample } \\
\text { with highest } \\
{ }^{3} \mathrm{He} /{ }^{4} \mathrm{He} \text { used }\end{array}$ & $\begin{array}{l}{ }^{3} \mathrm{He} /{ }^{4} \mathrm{He} \\
( \pm 1 \sigma)\end{array}$ & ${ }^{87} \mathrm{Sr} /{ }^{86} \mathrm{Sr}$ & ${ }^{143} \mathrm{Nd} /{ }^{144} \mathrm{Nd}$ & ${ }^{206} \mathrm{~Pb} /{ }^{204} \mathrm{~Pb}$ & ${ }^{207} \mathrm{~Pb} /{ }^{204} \mathrm{~Pb}$ & ${ }^{208} \mathrm{~Pb} /{ }^{204} \mathrm{~Pb}$ & Epsilon ${ }^{143} \mathrm{Nd}$ \\
\hline \multicolumn{10}{|l|}{$F O Z O-A$} \\
\hline Samoa $^{\mathrm{a}}$ & Ofu & Ofu-04-06 & $33.8 \pm 0.2$ & 0.704584 & 0.512827 & 19.189 & 15.571 & 39.202 & 4.2 \\
\hline Societies $^{\mathrm{a}}$ & Moorea & MO-01-01 & $17.0 \pm 1.6$ & 0.704621 & 0.512774 & 19.216 & 15.603 & 38.933 & 3.2 \\
\hline Macdonald $^{\mathrm{a}}$ & Macdonald & SO-47 64DS2 & $15.8 \pm 0.3$ & 0.703755 & 0.512777 & 19.46 & 15.61 & 39.27 & 3.2 \\
\hline Juan Fernandez ${ }^{b, c}$ & Mas a Tierra & PIN-8 & $17.2 \pm 0.3$ & 0.70363 & 0.512840 & 19.13 & 15.61 & 38.98 & 4.5 \\
\hline Reunion ${ }^{\mathrm{b}}$ & Reunion & VP1931 & $13.6 \pm 0.3$ & 0.704130 & 0.51284 & 18.88 & 15.59 & 38.96 & 4.5 \\
\hline Kerguelen $^{\mathrm{d}}$ & Heard & HB24A & $18.3 \pm 0.5$ & 0.704862 & 0.512705 & 18.776 & 15.588 & 39.170 & 1.8 \\
\hline Bouvet $^{b}$ & Bouvet & WJ8B & $12.4 \pm 1$ & 0.70371 & 0.51284 & 19.588 & 15.653 & 39.243 & 4.5 \\
\hline Marquesas $^{a}$ & Hiva Oa & HO-AT-1 & $14.4 \pm 1.4$ & 0.70471 & 0.512834 & 19.017 & 15.570 & 38.823 & 4.4 \\
\hline \multicolumn{10}{|l|}{$F O Z O-B$} \\
\hline Hawaii ${ }^{\mathrm{a}, \mathrm{c}}$ & Loihi & KK18-8 & $32.3 \pm 0.6$ & 0.703680 & 0.512945 & 18.448 & 15.477 & 38.189 & 6.5 \\
\hline Iceland $^{\mathrm{a}}$ & Westfjords & SEL-97 & $37.7 \pm 2.0$ & 0.703465 & 0.512969 & 18.653 & 15.473 & 38.453 & 7.0 \\
\hline Galapagoes $^{\mathrm{a}}$ & Fernandina & NSK 97-214 & $30.3 \pm 0.2$ & 0.703290 & 0.512937 & 19.080 & 15.537 & 38.711 & 6.4 \\
\hline Cape Verde ${ }^{b}$ & San Nicolau & SN-10 & $15.7 \pm 0.1$ & 0.703050 & 0.51296 & 19.538 & 15.586 & 38.964 & 6.7 \\
\hline Azores ${ }^{\mathrm{a}, \mathrm{c}}$ & Terciera & $\mathrm{T} 2$ & $11.3 \pm 0.8$ & 0.703520 & 0.512960 & 19.883 & 15.630 & 39.310 & 6.8 \\
\hline
\end{tabular}

If $\mathrm{Sr}, \mathrm{Nd}$ and $\mathrm{Pb}$ isotopes are unavailable for a sample with high ${ }^{3} \mathrm{He} /{ }^{4} \mathrm{He}$, they are estimated based on the criteria below and the estimated values are italicized in the table.

$\mathrm{High}{ }^{3} \mathrm{He} /{ }^{4} \mathrm{He}$ lavas erupted at deep submarine ridge environments are excluded, and include the following locations as summarized in Graham (2002): Southeast Indian ridge near Amsterdam and St. Paul (14.1 Ra), east and west rifts of the Easter microplate (11.7 Ra), Gulf of Tadjoura near Afar (14.7 Ra), southern Mid-Atlantic ridge near Shona and Discovery (12.3 and 15.2 Ra, respectively), Southwest Indian Ridge near Bouvet Island $(14.9 \mathrm{Ra})$ and the Manus Basin back-arc spreading center (15.1 Ra). However, sub-aerially erupted high ${ }^{3} \mathrm{He} /{ }^{4} \mathrm{He}$ lavas sampled at ridge-centered hotspots, including Bouvet Island (Kurz et al., 1998) and Iceland (Hilton et al., 1999), are included in the dataset. Additionally, high ${ }^{3} \mathrm{He} /{ }^{4} \mathrm{He}$ lavas erupted in continental settings are not considered, and include: Baffin Island (Stuart et al., 2003) and West Greenland picrites (Graham et al., 1998), Yellowstone (Graham et al., 2006) and Afar (Scarsi and Craig, 1996). Finally, high ${ }^{3} \mathrm{He} /{ }^{4} \mathrm{He}$ lavas erupted in back-arc environments, such as Rochambeau Bank (Poreda and Craig, 1992) and Manus Basin (Macpherson et al., 1998), are excluded from our treatment of the high ${ }^{3} \mathrm{He} /{ }^{4} \mathrm{He}$ mantle.

${ }^{\text {a }}$ Many of the high ${ }^{3} \mathrm{He} /{ }^{4} \mathrm{He}$ lavas in this table have a full complement of lithophile radiogenic isotope analyses measured on the same samples, and are from the following locations: The Galapagos (Kurz and Geist, 1999; Saal et al., 2007), Hawaii (Kurz et al., 1983; Staudigel et al., 1984), Samoa (Table 1), Iceland (Hilton et al., 1999), Societies (Hanyu and Kaneoka, 1997; Table 1), Marquesas (Castillo et al., 2007), Macdonald (Hémond et al., 1994; Moreira and Allègre, 2004) and Azores (Turner et al., 1997; Moreira et al., 1999).

b A full complement of $\mathrm{Sr}, \mathrm{Nd}$ and $\mathrm{Pb}$-isotope data do not exist for all the high ${ }^{3} \mathrm{He} /{ }^{4} \mathrm{He}$ samples listed in the table above. Values for the "missing" lithophile radiogenic isotopes (data in italics) are generated based on the following criteria. The high ${ }^{3} \mathrm{He} /{ }^{4} \mathrm{He}$ Cape Verde lava has $\mathrm{Sr}$ and $\mathrm{Pb}$ isotopes but lacks Nd isotopes (Doucelance et al., 2003). Sr and Nd-isotope data correlate well in the Cape Verde islands, and the Nd-isotope ratio for the Cape Verde sample is made by regression through existing data. The high ${ }^{3} \mathrm{He} /{ }^{4} \mathrm{He}$ Bouvet Island sample (Kurz et al., 1998) also has $\mathrm{Sr}$ and $\mathrm{Pb}$-isotope data, but lacks a Nd-isotope measurement. The missing Nd isotopic value is estimated by averaging existing Bouvet island data from O’Nions et al. (1977). A high ${ }^{3} \mathrm{He} /{ }^{4} \mathrm{He}$ sample from Reunion with Sr isotope data (Graham et al., 1990) lacks Nd and Pb-isotope data; Reunion lavas are isotopically uniform, and the GEOROC database (http://georoc.mpch-mainz.gwdg.de/georoc/) was used to estimate the $\mathrm{Nd}$ and $\mathrm{Pb}$ isotopic compositions for the Reunion sample. Sr and Nd-isotope data are reported for a sample with the second highest ${ }^{3} \mathrm{He} /{ }^{4} \mathrm{He}$ measured from Juan Fernandez (Farley et al., 1993), but Pbisotope data are missing; the high ${ }^{3} \mathrm{He} /{ }^{4} \mathrm{He}$ Juan Fernandez sample exhibits one of the least radiogenic Nd-isotope ratios (0.51284) in the Juan Fernandez suite, so Pb-isotope compositions $\left({ }^{206} \mathrm{~Pb} /{ }^{204} \mathrm{~Pb}\right.$ from 19.045 to 19.214) from three other Juan Fernandez samples (Gerlach et al., 1986) with the least radiogenic $\mathrm{Nd}$ isotopes $(0.51282-0.51284)$ were averaged to generate a Pb-isotope composition for the high ${ }^{3} \mathrm{He} /{ }^{4} \mathrm{He}$ lava.

${ }^{\mathrm{c}}$ When the ${ }^{3} \mathrm{He} /{ }^{4} \mathrm{He}$ ratios quoted above are lower than the maximum from a hotspot, it is because $\mathrm{Sr}, \mathrm{Nd}$ and/or $\mathrm{Pb}$-isotope ratios could not be estimated reliably for the sample, or because higher reported ${ }^{3} \mathrm{He} /{ }^{4} \mathrm{He}$ ratios were not measured as precisely (or were suspected of having a cosmogenic ${ }^{3} \mathrm{He}$ influence). For example, a ${ }^{3} \mathrm{He} /{ }^{4} \mathrm{He}$ value of $14.8 \mathrm{Ra}$ was reported for an Azores lava (Madureira et al., 2005), but lithophile radiogenic isotopes were not reported and a cosmogenic ${ }^{3} \mathrm{He}$ influence cannot be ruled out for this sample. Similarly, a value of up to 35.3 Ra has been reported from Loihi (Valbracht et al., 1997), but analytical uncertainties on this measurement were large and lithophile isotopes were not reported.

${ }^{\mathrm{d}} \mathrm{The} \mathrm{Sr}, \mathrm{Nd}$ and $\mathrm{Pb}$ isotopes of the Heard sample (Barling and Goldstein, 1990; Hilton et al., 1995) were not measured on the same sample as the ${ }^{3} \mathrm{He} /{ }^{4} \mathrm{He}$, but they were measured on a sample (69244) from the same flow.

continental crust, is an exception to the separation of Ofu and HIG lavas. Ofu's trend to a more enriched region of Nd-isotope space than that sampled by the HIG lavas is also clear $\left({ }^{143} \mathrm{Nd} /{ }^{144} \mathrm{Nd}<0.51285\right.$ in Ofu versus ${ }^{143} \mathrm{Nd} /$ ${ }^{144} \mathrm{Nd}>0.51290$ in HIG lavas). Previous work suggested that the Samoan data trends toward a similar high ${ }^{3} \mathrm{He} /{ }^{4} \mathrm{He}$ component as the HIG lavas (Farley et al., 1992; Hart et al., 1992). The new isotope data argue against this hypothesis because Ofu has ${ }^{3} \mathrm{He} /{ }^{4} \mathrm{He}$ as high as HIG but with more enriched ${ }^{87} \mathrm{Sr} /{ }^{86} \mathrm{Sr}$ and ${ }^{143} \mathrm{Nd} /{ }^{144} \mathrm{Nd}$. 
In order to place constraints on the $\mathrm{Sr}, \mathrm{Nd}$ and $\mathrm{Pb}$ isotope heterogeneity of the high ${ }^{3} \mathrm{He} /{ }^{4} \mathrm{He}$ mantle reservoir (Fig. 2), we have compiled a dataset of $\mathrm{Sr}, \mathrm{Nd}$ and $\mathrm{Pb}$ isotopes for lavas that are representative of the high ${ }^{3} \mathrm{He} /{ }^{4} \mathrm{He}$ OIB mantle. We include only the hotspots that have ${ }^{3} \mathrm{He} /{ }^{4} \mathrm{He}>11 \mathrm{Ra}$, thereby excluding hotspots such as Tristan, Gough, and St. Helena, etc., that do not sample a component from the high ${ }^{3} \mathrm{He} /{ }^{4} \mathrm{He}$ mantle. We also limit our discussion to just the single highest ${ }^{3} \mathrm{He} / \mathrm{He}$ sample from each high ${ }^{3} \mathrm{He}^{A} \mathrm{He}$ hotspot, in an attempt to define the $\mathrm{Sr}-\mathrm{Nd}-\mathrm{Pb}$-isotope composition of the highest ${ }^{3} \mathrm{He} /$ ${ }^{4} \mathrm{He}$ reservoir sampled by a hotspot. Finally, high ${ }^{3} \mathrm{He} /{ }^{4} \mathrm{He}$ lavas erupted at continental, back-arc and deep submarine ridge environments are excluded (see Table 2 for a list of specific samples from these three environments).

Using the above criteria, Table 2 lists the high ${ }^{3} \mathrm{He} /{ }^{4} \mathrm{He}$ samples that best represent the $\mathrm{Sr}, \mathrm{Nd}$ and $\mathrm{Pb}$ compositions of the high ${ }^{3} \mathrm{He} /{ }^{4} \mathrm{He}$ OIB mantle reservoir. Combined with the new Ofu data, the high ${ }^{3} \mathrm{He} /{ }^{4} \mathrm{He}$ OIB dataset in Table 2 suggests the existence of two isotopically distinct high ${ }^{3} \mathrm{He} /{ }^{4} \mathrm{He}$ reservoirs in the mantle. These two high ${ }^{3} \mathrm{He} /{ }^{4} \mathrm{He}$ reservoirs separate in the northern (boreal) and southern (austral) hemispheres (Fig. 2). The highest ${ }^{3} \mathrm{He} /{ }^{4} \mathrm{He}$ samples from each of the southern hemisphere hotspots, Macdonald seamount, Bouvet, Kerguelen, Juan Fernandez, Societies, Reunion and Marquesas appear to sample the more isotopically enriched, high ${ }^{3} \mathrm{He} /{ }^{4} \mathrm{He}$ mantle component found in Ofu lavas. By contrast, HIG lavas and two other northern hemisphere hotspots-Cape Verde and Azores-sample a more isotopically depleted, (or less isotopicallyenriched, see Section 4.5) high ${ }^{3} \mathrm{He} /{ }^{4} \mathrm{He}$ component than observed in southern hemisphere high ${ }^{3} \mathrm{He} /{ }^{4} \mathrm{He}$ lavas. The highest ${ }^{3} \mathrm{He} /{ }^{4} \mathrm{He}$ samples from the boreal and austral high ${ }^{3} \mathrm{He} /{ }^{4} \mathrm{He}$ hotspots separate toward the depleted and enriched ends, respectively, of the global ${ }^{87} \mathrm{Sr} /{ }^{86} \mathrm{Sr}-{ }^{143} \mathrm{Nd} /{ }^{144} \mathrm{Nd}$ OIB array (Fig. 2). Fig. 2 shows that there are two separate ${ }^{3} \mathrm{He} /{ }^{4} \mathrm{He}$ peaks in $\mathrm{Sr}-\mathrm{Nd}-\mathrm{He}$ isotope space: One peak is formed by the highest ${ }^{3} \mathrm{He} /{ }^{4} \mathrm{He}$ northern hemisphere samples and another peak, anchored by the high ${ }^{3} \mathrm{He} /{ }^{4} \mathrm{He}$ Ofu lava, is formed by the highest ${ }^{3} \mathrm{He} /{ }^{4} \mathrm{He}$ southern hemisphere samples. Samples with the highest ${ }^{3} \mathrm{He} /{ }^{4} \mathrm{He}$ from each of the boreal and austral FOZO hotspots also are distinguished isotopically inside the mantle tetrahedron formed by the isotopes of $\mathrm{Sr}, \mathrm{Nd}$ and $\mathrm{Pb}$. The boreal (FOZO-B) domain plots closer to the DMM-HIMU join while the austral (FOZO-A) domain plots closer to the EM1-EM2 join (Fig. 2). FOZO-A and FOZO-B also clearly separate in a mantle tetrahedron constructed from the isotopes of $\mathrm{Pb}$ (a figure of the $\mathrm{Pb}$-isotope tetrahedron is available as supplementary data in the Appendix).

\section{Discussion}

\subsection{FOZO-A and FOZO-B: some important caveats}

Unfortunately, there are limited numbers of hotspots with moderately high ${ }^{3} \mathrm{He} /{ }^{4} \mathrm{He}$ (from $11.3-18.3 \mathrm{Ra}, 9$ hotspots) and very high ${ }^{3} \mathrm{He} /{ }^{4} \mathrm{He}$ (>30 Ra, 4 hotspots); lithophile isotope data on lavas from many of these high ${ }^{3} \mathrm{He} /{ }^{4} \mathrm{He}$ hotspots are also limited (see Table 2). Therefore, we cannot exclude the possibility that the apparent hemispheric separation is related to sparse data, and that existing $\mathrm{He}, \mathrm{Sr}, \mathrm{Nd}$ and $\mathrm{Pb}$-isotope data do not yet adequately characterize the terrestrial mantle. Furthermore, the isotopic and hemispheric separation of the two FOZOs is not observed in all isotope projections: In ${ }^{3} \mathrm{He} /{ }^{4} \mathrm{He}$ vs. ${ }^{206} \mathrm{~Pb} /{ }^{204} \mathrm{~Pb}$ and ${ }^{3} \mathrm{He} /{ }^{4} \mathrm{He}$ vs. ${ }^{87} \mathrm{Sr} /{ }^{86} \mathrm{Sr}$ isotope spaces (not shown), the FOZO-A and FOZO-B fields overlap. However, in ${ }^{3} \mathrm{He} /{ }^{4} \mathrm{He}$ vs. ${ }^{143} \mathrm{Nd} /{ }^{144} \mathrm{Nd}-$ isotope space the two FOZOs are completely resolved (Fig. 2).

An additional characteristic of the "two FOZOs" model is that the isotopic and hemispheric distinction is not always observed in the highest ${ }^{3} \mathrm{He} /{ }^{4} \mathrm{He}$ lavas erupted in continental, back-arc and deep submarine mid-ocean ridge settings. One possible explanation is that mantle plume interaction with the shallow geochemical reservoirs in these three environments can decouple the deep mantle ${ }^{3} \mathrm{He} /{ }^{4} \mathrm{He}$ signatures from the associated $\mathrm{Sr}, \mathrm{Nd}$ and $\mathrm{Pb}$ isotopes. If so, then the high ${ }^{3} \mathrm{He} /{ }^{4} \mathrm{He}$ ratios measured in lavas from these three settings cannot be traced to the same source components as the $\mathrm{Sr}, \mathrm{Nd}$ and $\mathrm{Pb}$ isotopes. High ${ }^{3} \mathrm{He} /{ }^{4} \mathrm{He}$ lavas erupted in continental settings may have suffered crustal assimilation such that the $\mathrm{Sr}, \mathrm{Nd}$ and $\mathrm{Pb}$ isotopes are not representative of the high ${ }^{3} \mathrm{He} /{ }^{4} \mathrm{He}$ mantle. For example, a high ${ }^{3} \mathrm{He} /{ }^{4} \mathrm{He}$ Baffin Island sample (43.9 Ra; Stuart et al., 2003) with the least depleted ${ }^{143} \mathrm{Nd} /{ }^{144} \mathrm{Nd}$ in the suite-0.512730-is inferred to be crustally contaminated, and is not interpreted to be a northern hemisphere expression of FOZO-A. High ${ }^{3} \mathrm{He} /{ }^{4} \mathrm{He}$ lavas erupted in back-arc environments may not have lithophile isotope ratios that reflect the high ${ }^{3} \mathrm{He} /{ }^{4} \mathrm{He}$ mantle source, owing to possible involvement of slab-derived fluids that may affect the $\mathrm{Sr}, \mathrm{Nd}$ and $\mathrm{Pb}$ isotopes (even though such fluids may have a negligible effect on the ${ }^{3} \mathrm{He} /{ }^{4} \mathrm{He}$ ratios; Macpherson et al., 1998). The high ${ }^{3} \mathrm{He} /{ }^{4} \mathrm{He}$ signatures observed in deeply erupted submarine ridge lavas may host $\mathrm{Sr}, \mathrm{Nd}$ and $\mathrm{Pb}$ isotopes that reflect entrainment of the shallow depleted mantle. However, we presume that the high plume flux necessary for the generation of a sub-aerially-exposed, ridgecentered hotspot volcano enhances the plume contribution in the erupted lavas, thus overwhelming the depleted 
upper mantle component. Therefore, sub-aerially erupted Bouvet Island and Iceland high ${ }^{3} \mathrm{He} /{ }^{4} \mathrm{He}$ lavas are included in the database (both lavas host $\mathrm{Sr}, \mathrm{Nd}$ and $\mathrm{Pb}$ isotopes that more enriched than nearby ridges, and are taken to reflect a plume component).

How can high ${ }^{3} \mathrm{He} /{ }^{4} \mathrm{He}$, deep mantle signatures be preserved and become decoupled from the deep mantle $\mathrm{Sr}, \mathrm{Nd}$ and $\mathrm{Pb}$ signatures in continental, back-arc and deep submarine ridge environments? As a stimulus for further investigation, we suggest that the $\mathrm{He} /(\mathrm{Sr}, \mathrm{Nd}, \mathrm{Pb})$ ratios may be higher in the high ${ }^{3} \mathrm{He} /{ }^{4} \mathrm{He}$ mantle (or mantle melt) than in the shallow contaminating reservoirs found in these three geological settings. In this way, high ${ }^{3} \mathrm{He} /{ }^{4} \mathrm{He}$ signatures often may be little affected by contamination from shallow reservoirs while $\mathrm{Sr}, \mathrm{Nd}$ and $\mathrm{Pb}$ isotopes in such lavas can be strongly decoupled from the original high ${ }^{3} \mathrm{He} /{ }^{4} \mathrm{He}$ mantle source.

\subsection{FOZO-A vs. FOZO-B: is the difference sediment?}

The isotopic enrichment observed in FOZO-A lavas, particularly from Ofu, relative to the FOZO-B reservoir is not easily reconciled with existing models for the evolution of the high ${ }^{3} \mathrm{He} /{ }^{4} \mathrm{He}$ mantle. One hypothesis for the generation of the relative lithophile isotope and trace element enrichment in high ${ }^{3} \mathrm{He} /{ }^{4} \mathrm{He}$ lavas from Samoa maintains that the high ${ }^{3} \mathrm{He} /{ }^{4} \mathrm{He}$ mantle beneath this hotspot was recently contaminated by rapidly cycled sediment from the nearby Tonga trench (Farley, 1995). However, evidence from $\mathrm{Pb}$-isotopes rules out modern marine sediment contamination of the Samoan high ${ }^{3} \mathrm{He} /{ }^{4} \mathrm{He}$ mantle. The sediment-OIB discriminating properties (Hart, 1988) of $\Delta^{207} \mathrm{~Pb} /{ }^{204} \mathrm{~Pb}-\Delta^{208} \mathrm{~Pb} /{ }^{204} \mathrm{~Pb}$-isotope space (Hart, 1984) show that Samoan basalts and modern global marine sediments (Plank and Langmuir, 1998) exhibit non-overlapping fields with diverging trends (Fig. 3) (Jackson et al., 2007). Pb-isotope data thus preclude the presence of modern marine sediment (including sediments outboard of the Tonga trench) in the FOZO-A mantle sampled by Ofu lavas.

$\mathrm{Sr}, \mathrm{Nd}$ and $\mathrm{Pb}$-isotope compositions for the high ${ }^{3} \mathrm{He} /{ }^{4} \mathrm{He}$ Moorea lava (Hanyu and Kaneoka, 1997) provide further evidence that the more enriched radiogenic isotope compositions of Samoan high ${ }^{3} \mathrm{He} /{ }^{4} \mathrm{He}$ lavas (compared to HIG lavas) are not necessarily a result of rapidly cycled, subducted sediment (Table 1). Moorea island is not located near a subduction zone, yet the high ${ }^{3} \mathrm{He} /{ }^{4} \mathrm{He}$ Moorea sample has ${ }^{87} \mathrm{Sr} /{ }^{86} \mathrm{Sr},{ }^{143} \mathrm{Nd} /{ }^{144} \mathrm{Nd}$ and ${ }^{206} \mathrm{~Pb} /{ }^{204} \mathrm{~Pb}$-isotope ratios similar to Ofu basalts.

The observation of elevated trace element concentrations in Samoan high ${ }^{3} \mathrm{He} /{ }^{4} \mathrm{He}$ lavas (relative to $\mathrm{HIG}$ high ${ }^{3} \mathrm{He} /{ }^{4} \mathrm{He}$ lavas) has been used as evidence for recent

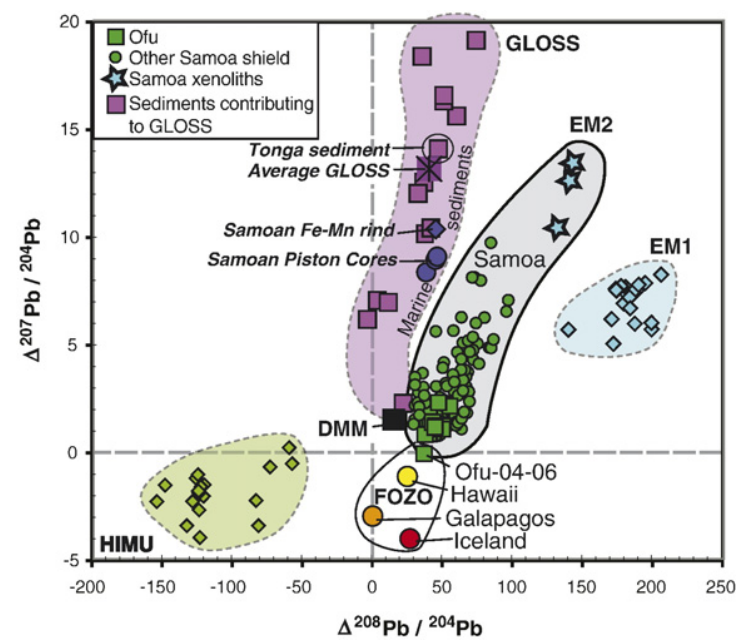

Fig. 3. In $\Delta^{207} \mathrm{~Pb} /{ }^{204} \mathrm{~Pb}-\Delta^{208} \mathrm{~Pb} /{ }^{204} \mathrm{~Pb}$-isotope space (Hart 1984 , 1988), Samoan basalts (including Ofu basalts) and global marine sediments exhibit non-overlapping fields with diverging trends. The Samoan data are plotted with oceanic sediments (the Tonga sediment is circled) contributing to global subducting sediment (GLOSS) from Plank and Langmuir (1998). Samoan lavas from Ofu Island plot close to the highest ${ }^{3} \mathrm{He} /{ }^{4} \mathrm{He}$ lavas from Hawaii, Iceland and Galapagos. Samoan xenoliths from Savai'i island are plotted as stars (Hauri et al., 1993). Other plotted Pb-isotope data include endmember MORB (average of normal ridge segments; Su, 1986), EM1 (Pitcairn; Eisele et al., 2002; Hart and Hauri, unpubl. data) and HIMU (Mangaia and Tubuai; Hauri and Hart, 1993; Woodhead, 1996). The figure is adapted from Jackson et al. (2007), and data for sediments from the Samoan region (piston cores) and the ferromanganese rind are from the same source. $\mathrm{Pb}$-isotope data preclude the presence of modern marine sediment (including sediment recently subducted into the Tonga trench) in the FOZO-A mantle sampled by Ofu lavas.

sediment contamination of the Samoan high ${ }^{3} \mathrm{He} /{ }^{4} \mathrm{He}$ mantle (Farley, 1995). However, our favored explanation for the elevated trace element concentrations in the Ofu (and Moorea) high ${ }^{3} \mathrm{He} /{ }^{4} \mathrm{He}$ lavas is that they are products of low degrees of melting, a mechanism that can greatly increase the trace element concentrations in lavas relative to their mantle source. Ofu and Moorea high ${ }^{3} \mathrm{He} /{ }^{4} \mathrm{He}$ lavas are alkaline, a petrologic feature that is uncommon among high ${ }^{3} \mathrm{He} /{ }^{4} \mathrm{He} \mathrm{HIG}$ lavas and one that is likely to be a result of low degrees of mantle melting. Therefore, the alkaline nature of Samoan high ${ }^{3} \mathrm{He} /{ }^{4} \mathrm{He}$ lavas may help resolve the apparent paradox of high $\mathrm{U}$ and Th concentrations in Samoan lavas that also host high ${ }^{3} \mathrm{He} /{ }^{4} \mathrm{He}$ ratios (Fig. 4).

Although the Samoan plume exhibits a $\left(\right.$ low $\left.{ }^{3} \mathrm{He} /{ }^{4} \mathrm{He}\right)$ component with recycled sediment, the high ${ }^{3} \mathrm{He} /{ }^{4} \mathrm{He}$ Samoan lavas from Ofu exhibit no evidence for an ancient recycled sediment component. The most enriched lavas from Samoa display evidence for an ancient recycled sediment component (White and Hofmann, 1982; Wright 


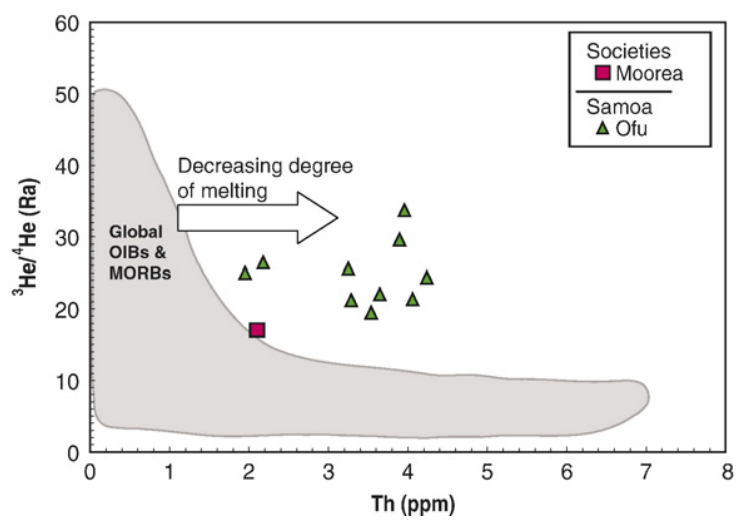

Fig. $4 .{ }^{3} \mathrm{He} /{ }^{4} \mathrm{He}-\mathrm{Th}$ for Ofu lavas compared to other OIBs and MORBs. Ofu basalts and the high ${ }^{3} \mathrm{He} /{ }^{4} \mathrm{He}$ basalt from Moorea (MO-01-01) exhibit higher Th concentrations than high ${ }^{3} \mathrm{He} /{ }^{4} \mathrm{He}$ basalts from other hotspots (see Table 1). The field for global OIBs (excluding Samoa) and MORBs is from Class and Goldstein (2005). All Ofu and Moorea Th data shown are by ICP, and the Ofu Th data are not corrected for olivine or cpx fractionation. The high Th concentrations in the Ofu and Moorea high ${ }^{3} \mathrm{He} /{ }^{4} \mathrm{He}$ basalts are interpreted as resulting from lower degrees of melting, a hypothesis that is consistent with the alkaline nature of the lavas from these two islands.

and White, 1987; Farley et al., 1992), including high ${ }^{87} \mathrm{Sr} /{ }^{86} \mathrm{Sr}$ ratios (up to 0.7216 ) and low ${ }^{3} \mathrm{He} /{ }^{4} \mathrm{He}$ ratios ( $<5 \mathrm{Ra}$; Jackson et al., 2007). By contrast, ${ }^{87} \mathrm{Sr} /{ }^{86} \mathrm{Sr}$ and ${ }^{143} \mathrm{Nd} /{ }^{144} \mathrm{Nd}$ isotopes measured in Ofu lavas are among the most depleted in Samoa (Table 1). Furthermore, the positive $\mathrm{Pb}$ anomalies and high $\mathrm{Ba} / \mathrm{Nb}$ ratios that are diagnostic of sediment are observed in the most isotopically enriched Samoan lavas, but are absent in the isotopically depleted Ofu lavas (Fig. 5). The $\mathrm{Ba} / \mathrm{Nb}$ and $\mathrm{Pb} / \mathrm{Pb} *$ measured in the HIG (FOZO-B) high ${ }^{3} \mathrm{He} /{ }^{4} \mathrm{He}$ lavas are indistinguishable from the Ofu lavas, providing further evidence that the Ofu lavas do not host an ancient recycled sediment component (Fig. 5).

\subsection{Ofu lavas from recycled harzburgite?}

Some recent models advocate a role for ancient, depleted, high ${ }^{3} \mathrm{He} /(\mathrm{U}+\mathrm{Th})$ harzburgitic mantle lithosphere in the formation of the high ${ }^{3} \mathrm{He} /{ }^{4} \mathrm{He}$ mantle domain (Anderson, 1998; Parman et al., 2005; Heber et al., 2007). This assumes that cpx-poor melt residues may have the property of increased ${ }^{3} \mathrm{He} /(\mathrm{U}+\mathrm{Th})$ relative to the initial, unmelted source (Parman et al., 2005), and thus may preserve high ${ }^{3} \mathrm{He} /{ }^{4} \mathrm{He}$ ratios over time. Trace element budgets in abyssal peridotites provide a critical test of the hypothesis that recycled harzburgite is involved in the source of high ${ }^{3} \mathrm{He} /{ }^{4} \mathrm{He}$ OIB lavas. While a harzburgite lithology is consistent with the cpx-poor nature of the upper oceanic lithosphere, the abyssal peridotites that comprise the upper oceanic lithosphere are too depleted in incompatible trace elements (Workman and Hart, 2005) to act as a source for the high ${ }^{3} \mathrm{He} /{ }^{4} \mathrm{He}$ Ofu basalts. For example, the maximum $\mathrm{Sr}$ concentration that can be generated by extremely low degrees of aggregated fractional melting of modern harzburgitic abyssal peridotites (samples with $<5 \% \mathrm{cpx}$, with an average reconstructed bulk rock $\mathrm{Sr}$ concentration of $\sim 0.02 \mathrm{ppm}$; see figure available as supplementary data in the Appendix) is $\sim 5 \mathrm{ppm}$, which is far below the $\mathrm{Sr}$ concentrations ( $\sim 600 \mathrm{ppm}$ ) of primary Ofu lavas. Trace element budgets in modern abyssal peridotites suggest that Ofu basalts are
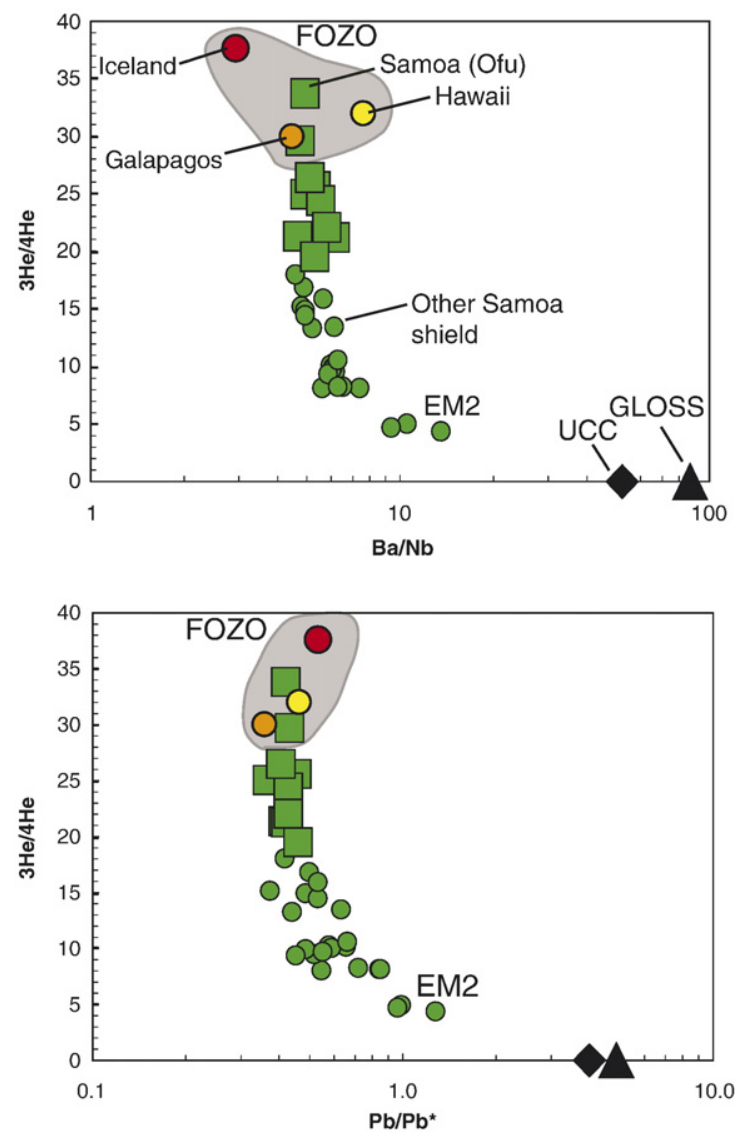

Fig. $5 .{ }^{3} \mathrm{He} /{ }^{4} \mathrm{He}$ variation with $\mathrm{Ba} / \mathrm{Nb}$ and $\mathrm{Pb} / \mathrm{Pb}^{*}$ in Samoan lavas and high ${ }^{3} \mathrm{He} /{ }^{4} \mathrm{He}$ samples from Hawaii (Kurz et al., 1982), Iceland (Hilton et al., 1999) and the Galapagos (Kurz and Geist, 1999; Saal et al., 2007). $\mathrm{Ba} / \mathrm{Nb}$ ratios in high ${ }^{3} \mathrm{He} /{ }^{4} \mathrm{He}$ lavas from all four hotspots are low, and do not indicate input from marine sediment (GLOSS; Plank and Langmuir, 1998) or upper continental crust (UCC; Rudnick and Gao, 2003). $\mathrm{Pb} / \mathrm{Pb}$ * values in high ${ }^{3} \mathrm{He} /{ }^{4} \mathrm{He}$ lavas are also unlike GLOSS and UCC. On the other hand, the enriched (EM2) Samoan lavas have low ${ }^{3} \mathrm{He} /{ }^{4} \mathrm{He}$, high $\mathrm{Ba} / \mathrm{Nb}$ and high $\mathrm{Pb} / \mathrm{Pb}^{*}$, values that suggest a recycled sediment signature (Jackson et al., 2007). All trace element data were measured by ICP, but trace element data from the Iceland and Hawaii samples are unpublished. $\mathrm{Pb} / \mathrm{Pb}^{*}=\mathrm{Pb}_{\mathrm{N}} / \sqrt{ }\left(\mathrm{Ce}_{\mathrm{N}} \times \mathrm{Nd}_{\mathrm{N}}\right)$, where $\mathrm{N}$ signifies normalization to primitive mantle (McDonough and Sun, 1995). 
not the melts of ancient, recycled (depleted) oceanic upper mantle lithosphere.

The base of the oceanic mantle lithosphere, which is thought to have a lherzolitic composition similar to DMM (Workman and Hart, 2005), can produce the Sr concentrations observed in Ofu lavas if it is melted at low degrees. Lherzolitic melt residues also may have the property of increased ${ }^{3} \mathrm{He} /(\mathrm{U}+\mathrm{Th})$ relative to the initial, unmelted source (Parman et al., 2005). However, results from recent helium partitioning experiments yield conflicting results (Heber et al., 2007; see Section 4.5 below), and suggest that lherzolitic melt residues will have greatly diminished ${ }^{3} \mathrm{He} /(\mathrm{U}+\mathrm{Th})$. The observation of radiogenic ${ }^{187} \mathrm{Os} /{ }^{188} \mathrm{Os}$ in high ${ }^{3} \mathrm{He} /{ }^{4} \mathrm{He}$ lavas from Iceland is inconsistent with a purely peridotitic origin of the high ${ }^{3} \mathrm{He} /{ }^{4} \mathrm{He}$ mantle (Brandon et al., 2007), and suggest that helium partitioning studies based on melting pure peridotite compositions may not be applicable to melting of the high ${ }^{3} \mathrm{He} /{ }^{4} \mathrm{He}$ reservoirs in the earth's mantle.

\subsection{Ofu lavas from chondritic primitive (undegassed) mantle or regassed mantle?}

An alternative hypothesis suggests that high ${ }^{3} \mathrm{He} /{ }^{4} \mathrm{He}$ Samoan lavas are derived from chondritic primitive mantle (referred to as PHEM; Farley et al., 1992). However, such a model fails to explain the non-chondritic ${ }^{143} \mathrm{Nd} /{ }^{144} \mathrm{Nd}$ and ${ }^{206} \mathrm{~Pb} /{ }^{204} \mathrm{~Pb}$ ratios obtained in Ofu lavas: the ${ }^{143} \mathrm{Nd} /{ }^{144} \mathrm{Nd}$ and ${ }^{206} \mathrm{~Pb} /{ }^{204} \mathrm{~Pb}$ ratios of Ofu lavas, which are 0.51283 and 19.19 , respectively, are much higher than the corresponding chondritic primitive mantle values, which are 0.512611 (Boyet and Carlson, 2005) and 17.675, respectively.

Another, more recent model attempts to reconcile the non-chondritic lithophile isotopes in high ${ }^{3} \mathrm{He} /{ }^{4} \mathrm{He}$ lavas assumes that a depleted upper mantle source was "regassed" by mixing with a small proportion of heliumrich, high ${ }^{3} \mathrm{He} /{ }^{4} \mathrm{He}$ chondritic mantle (Stuart et al., 2003; Ellam and Stuart, 2004). This model suggested that regassed, depleted mantle is in the source of the high ${ }^{3} \mathrm{He} /{ }^{4} \mathrm{He}$ ratios found in basalts associated with the protoIceland plume (PIP). However, Ofu lavas fall well outside of the array formed by PIP lavas in ${ }^{3} \mathrm{He} /{ }^{4} \mathrm{He}-{ }^{143} \mathrm{Nd} /{ }^{144} \mathrm{Nd}-$ isotope space (Ellam and Stuart, 2004), highlighting the need for a model that includes a heterogeneous high ${ }^{3} \mathrm{He} /{ }^{4} \mathrm{He}$ mantle.

\subsection{Implications of ${ }^{142} \mathrm{Nd} /{ }^{144} \mathrm{Nd}$ for "re-enrichment" of the high ${ }^{3} \mathrm{He}{ }^{4} \mathrm{He}$ mantle}

The discovery of ${ }^{142} \mathrm{Nd} /{ }^{144} \mathrm{Nd}$ ratios in accessible terrestrial rocks that are higher than chondrite (Boyet and
Carlson, 2005) has important consequences for the origin and evolution of the two FOZOs. The terrestrial ${ }^{142} \mathrm{Nd} /{ }^{144} \mathrm{Nd}$ anomaly indicates that all measured terrestrial rocks were derived from a reservoir that had superchronditic $\mathrm{Sm} / \mathrm{Nd}$ during the lifetime of ${ }^{146} \mathrm{Sm}$, as imperfect mixing of nucleosynthetic material in the solar nebula (Ranen and Jacobsen, 2006) does not explain the terrestrial excess in ${ }^{142} \mathrm{Nd}$ (Hidaka et al., 2003; Andreasen and Sharma, 2006; Carlson et al., 2007; Wombacher and Becker, 2007). For example, if $\mathrm{Sm} / \mathrm{Nd}$ ratios were heterogeneously distributed in the solar nebula at the time of accretion, bulk silicate earth (BSE) may have acquired higher $\mathrm{Sm} / \mathrm{Nd}$ and thus higher time-integrated ${ }^{142} \mathrm{Nd} /{ }^{144} \mathrm{Nd}$ ratios than chondrites (Boyet and Carlson, 2006). If the assumptions for a non-chondritic BSE are valid (Boyet and Carlson, 2006), then both FOZO-A and FOZO-B are isotopically enriched relative to BSE (Fig. 6, top panel). Alternatively, if BSE has chondritic $\mathrm{Sm} / \mathrm{Nd}$, the terrestrial ${ }^{142} \mathrm{Nd} /{ }^{144} \mathrm{Nd}$ anomaly in accessible terrestrial mantle rocks could have been generated by an early, global terrestrial differentiation event within $30 \mathrm{Myr}$ of accretion (Boyet and Carlson, 2005). In this case, the resulting early depleted reservoir (EDR) has superchondritic $\mathrm{Sm} / \mathrm{Nd}$ and evolves superchondritic ${ }^{142} \mathrm{Nd} /{ }^{144} \mathrm{Nd}$ (a complementary hidden early enriched reservoir, or EER, evolved sub-chondritic ${ }^{142} \mathrm{Nd} /{ }^{144} \mathrm{Nd}$; Boyet and Carlson, 2005). The FOZO reservoirs exhibit ${ }^{143} \mathrm{Nd} /{ }^{144} \mathrm{Nd}$ ratios that are lower (more enriched) than the minimum ${ }^{143} \mathrm{Nd} /{ }^{144} \mathrm{Nd}$ of the EDR (Fig. 6, bottom panel). If the FOZO reservoirs (like all accessible terrestrial mantle rocks) were ultimately derived from the EDR at some point in earth's history, then the high ${ }^{3} \mathrm{He} /{ }^{4} \mathrm{He}$ FOZO mantle has been re-enriched since the early differentiation event. In summary, if the terrestrial ${ }^{142} \mathrm{Nd} /{ }^{144} \mathrm{Nd}$ anomaly relative to chondrites is due to the decay of ${ }^{146} \mathrm{Sm}$, the observed ${ }^{143} \mathrm{Nd} /{ }^{144} \mathrm{Nd}$ ratios in FOZO-A and FOZO-B lavas require that they were re-enriched relative to either a non-chondritic BSE or the EDR.

There are a number of mechanisms by which the high ${ }^{3} \mathrm{He} /{ }^{4} \mathrm{He}$ mantle could have been re-enriched. However, the enriched material added to the high ${ }^{3} \mathrm{He} /{ }^{4} \mathrm{He}$ reservoirs must also have the property of preserving a high ${ }^{3} \mathrm{He} /{ }^{4} \mathrm{He}$ signature over time. Thus, re-enrichment by addition of recycled sediments seems unlikely, as lavas exhibiting clear evidence of sediment recycling, such as the high ${ }^{87} \mathrm{Sr} /{ }^{86} \mathrm{Sr}$ Samoan lavas from Samoa, exhibit low ${ }^{3} \mathrm{He} /{ }^{4} \mathrm{He}$ (Jackson et al., 2007). On the other hand, re-enrichment by addition of recycled (oceanic crust) eclogite plums to a high ${ }^{3} \mathrm{He} /{ }^{4} \mathrm{He}$ mantle source may not necessarily diminish the high ${ }^{3} \mathrm{He} /{ }^{4} \mathrm{He}$ signature (Brandon et al., 2007). As an alternative to re-enrichment by eclogite addition, depleted oceanic mantle lithosphere 
that has been re-enriched (metasomatized) with melt may serve as a source for high ${ }^{3} \mathrm{He} /{ }^{4} \mathrm{He}$ basalts (White, 2005). However, if the re-enriching melt is a result of imperfect melt extraction near a mid-ocean ridge (Workman et al., 2004), the ${ }^{3} \mathrm{He} /(\mathrm{U}+\mathrm{Th})$ of the melt will have to be similar to or higher than DMM to preserve high ${ }^{3} \mathrm{He} /{ }^{4} \mathrm{He}$ in the recycled upper oceanic mantle lithosphere over time (i.e., following subduction and isolation in the lower mantle). This condition requires that the compatibility of helium is similar to or lower than $\mathrm{U}$ and $\mathrm{Th}$ during peridotite melting.

However, such partitioning behavior is inconsistent with the helium partitioning results of Parman et al. (2005). Recent helium partitioning results of Heber et al. (2007) do suggest that $\mathrm{He}$ is less compatible than U and Th during peridotite melting (assuming a DMM lherzolite lithology from Workman and Hart (2005) and $\mathrm{U}$ and Th partition coefficients from Kelemen et al. (2004)). If the partitioning results of Heber et al. (2007) are correct, then oceanic mantle lithosphere hosting trapped melt may preserve high ${ }^{3} \mathrm{He} /{ }^{4} \mathrm{He}$ over time. Thus, long-term isolation of melt-impregnated oceanic

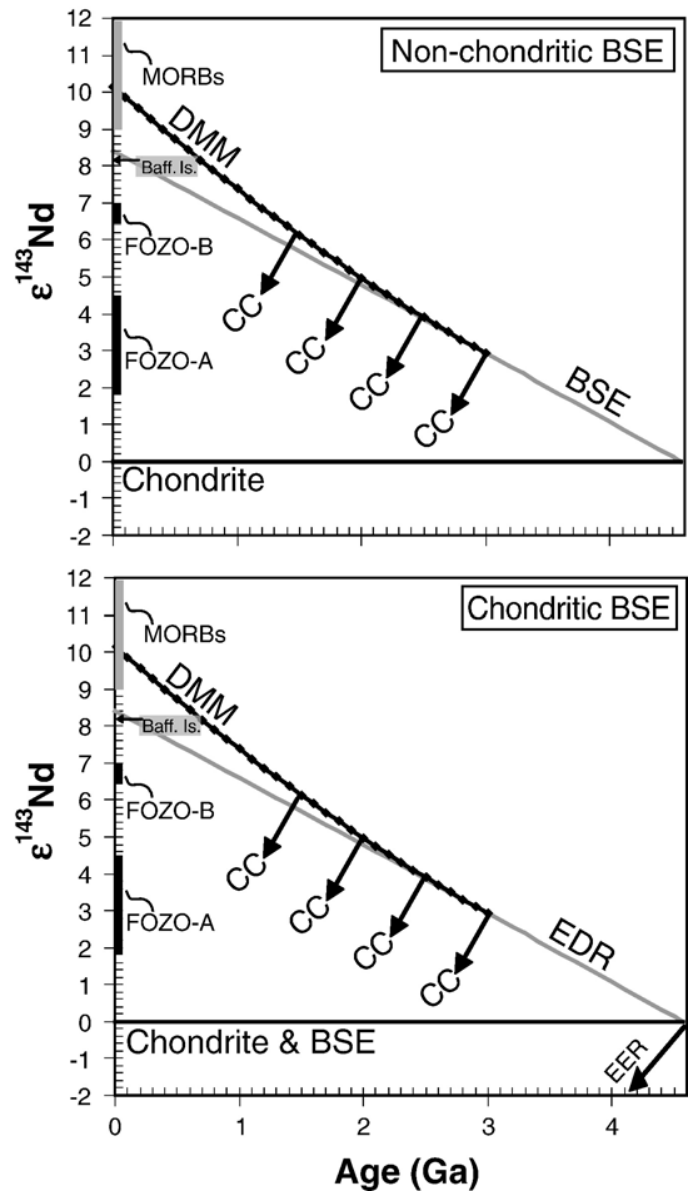

mantle lithosphere may provide a viable mechanism for preserving a high ${ }^{3} \mathrm{He} /{ }^{4} \mathrm{He}$ signature, and may have potential for describing the radiogenic isotope compositions and trace element budgets observed in global high ${ }^{3} \mathrm{He} /{ }^{4} \mathrm{He}$ lavas.

\subsection{Origin of the hemispheric separation of FOZO-A and FOZO-B: hints from the DUPAL anomaly}

The observation of a southern hemisphere high ${ }^{3} \mathrm{He} /{ }^{4} \mathrm{He}$ domain that is isotopically more enriched than its northern hemisphere counterpart is reminiscent of the DUPAL anomaly (Hart, 1984)-a globe-encircling feature of isotopic enrichment observed primarily in the southern hemisphere mantle-and indicates a long-term separation of the earth's northern and southern hemisphere high ${ }^{3} \mathrm{He} /{ }^{4} \mathrm{He}$ mantle. While there are a number of processes by which the re-enriched high ${ }^{3} \mathrm{He} /{ }^{4} \mathrm{He}$ mantle can be generated, the mechanisms responsible for the hemispheric separation, and long-term preservation, of two isotopically distinct FOZO reservoirs are elusive.

Like the high ${ }^{3} \mathrm{He} /{ }^{4} \mathrm{He}$ reservoir (Kurz et al., 1982; Hart et al., 1992) the DUPAL anomaly was suggested to be an ancient feature residing in the lower mantle (Hart, 1988; Castillo, 1988). The DUPAL anomaly is the only

Fig. 6. Implications of terrestrial ${ }^{142} \mathrm{Nd} /{ }^{144} \mathrm{Nd}$ anomalies for the ${ }^{143} \mathrm{Nd} /{ }^{144} \mathrm{Nd}$ evolution of BSE and the origin of the two FOZOs. If the observed superchondritic terrestrial mantle ${ }^{142} \mathrm{Nd} /{ }^{144} \mathrm{Nd}$ ratios (Boyet and Carlson, 2005) were generated by ${ }^{146} \mathrm{Sm}$ decay, either 1.) (top panel) the earth accreted from non-chondritic material and BSE has superchondritic $\mathrm{Sm} / \mathrm{Nd}$, or 2.) (bottom panel) BSE is chondritic but underwent an early depletion event and all available terrestrial mantle rocks derive from an early depleted reservoir (EDR) with superchondritic Sm/Nd. All calculations are after Boyet and Carlson (2005, 2006), and assume a chondrite average ${ }^{147} \mathrm{Sm} /{ }^{144} \mathrm{Nd}$ of 0.1948 , ${ }^{143} \mathrm{Nd} /{ }^{144} \mathrm{Nd}$ of 0.512611 , a solar system initial ${ }^{146} \mathrm{Sm} /{ }^{144} \mathrm{Sm}$ of 0.008 , and an identical age of $4.567 \mathrm{Ga}$ for the accretion time of the earth (top panel) and for the early differentiation event (bottom panel). Given these assumptions, the non-chondritic BSE and the EDR require ${ }^{147} \mathrm{Sm} /{ }^{144} \mathrm{Nd}$ ratios of $\sim 0.209$ to generate the ${ }^{142} \mathrm{Nd} /{ }^{144} \mathrm{Nd}$ anomalies that are $20 \mathrm{ppm}$ higher than chondrite (later formation times for the accretion of the earth, or for the early differentiation event, require even higher $\mathrm{Sm} / \mathrm{Nd}$ ratios). Thus, the lowest present-day ${ }^{143} \mathrm{Nd} /{ }^{144} \mathrm{Nd}$ value for a non-chondritic BSE and the EDR is $0.51304\left(\varepsilon^{143} \mathrm{Nd}=+8.4\right)$. Both FOZOs exhibit ${ }^{143} \mathrm{Nd} /{ }^{144} \mathrm{Nd}$ values lower than the non-chondritic BSE (top panel) and the EDR (bottom panel), and both FOZOs thus exhibit evidence for re-enrichment. Starting at $3 \mathrm{Ga}$, the DMM reservoir evolved by continuous extraction of continental crust (Workman and Hart, 2005) from the non-chondritic BSE (top panel) or from the EDR (bottom panel); DMM calculations are identical to Boyet and Carlson (2006). The trajectories of CC and EER are estimated. CC is not extracted as a single event, but is continuously extracted after $3 \mathrm{Ga}$. The MORB field is from Boyet and Carlson (2005) and FOZO-A and FOZO-B are from Table 2; the Baffin Island (Baff. Is.) high ${ }^{3} \mathrm{He} /{ }^{4} \mathrm{He}$ lava (Stuart et al., 2003) is plotted for reference. $\varepsilon_{\mathrm{Nd}}(\mathrm{t})=\left[{ }^{143} \mathrm{Nd} /\right.$ $\left.{ }^{144} \mathrm{Nd}_{\text {Sample }}(t) /{ }^{143} \mathrm{Nd} /{ }^{144} \mathrm{Nd}_{\text {Chondrite }}(t)-1\right] \times 10^{4}$. 
other mantle domain suggested to occupy similar, hemispheric proportions. The DUPAL anomaly shows that the southern hemisphere exhibits generally more isotopically enriched mantle domains than the northern hemisphere, and we find a similar southern hemisphere enrichment in the high ${ }^{3} \mathrm{He} /{ }^{4} \mathrm{He}$ FOZO-A reservoir; the depletion in the northern hemisphere DUPAL reference reservoir is mirrored in the FOZO-B reservoir. The geographic and geochemical similarities between the FOZO and DUPAL reservoirs suggest that their origin may have been linked.

One hypothesis for the formation of the DUPAL domain is that oceanic mantle and crustal lithosphere were injected into the mantle, thereby enriching this region of the mantle. This model has the advantage of being compatible with two of the possible re-enrichment mechanisms suggested for the FOZO reservoirs in Section 4.5: 1.) oceanic crustal eclogite plums were added to the depleted high ${ }^{3} \mathrm{He} /{ }^{4} \mathrm{He}$ mantle via subduction, or 2.) reenriched (metasomatized by melt near a mid-ocean ridge) oceanic mantle lithosphere was subducted and isolated in the (deep?) mantle and became the high ${ }^{3} \mathrm{He} /{ }^{4} \mathrm{He}$ mantle domain. These injection models may produce a random pattern of isotopic enrichment throughout the mantle, with no coherent hemispheric pattern (Hart, 1984). However, if injection were focused around the perimeter of a supercontinent during a period of anomalous subduction, a hemispheric pattern in the FOZO and DUPAL reservoirs might emerge. This model would suggest that the hemispheric and isotopic separation may be a surviving artifact of the paleo-arrangement of the subduction zones and continents during the formation of the FOZO reservoirs. While the timing of the formation of the FOZO reservoirs is unknown, we note that the Northern Hemisphere Reference Line (NHRL) separates the two FOZOs in ${ }^{207} \mathrm{~Pb} /{ }^{204} \mathrm{~Pb}-{ }^{206} \mathrm{~Pb} /{ }^{204} \mathrm{~Pb}$-isotope space (see figure included in the supplementary data in the Appendix), possibly suggesting a similar formation time $(\sim 1.8 \mathrm{Ga})$ for the DUPAL and FOZO reservoirs $(\mathrm{Pb}-$ isotope ratios in high ${ }^{3} \mathrm{He} /{ }^{4} \mathrm{He}$ lavas are displaced from the Geochron and preclude coeval formation of the FOZO and the hypothetical EDR reservoirs).

\subsection{FOZO-A and FOZO-B: implications for mantle dynamics}

A clear implication of the isotopic and geographic separation of the two high ${ }^{3} \mathrm{He} /{ }^{4} \mathrm{He}$ reservoirs is that they had to be isolated from each other for long timescales. The long-term separation of the two FOZO domains requires preservation despite convective stirring, a mechanism that efficiently attenuates mantle heterogeneities (van Keken et al., 2002). However, the hemispheric heterogeneity in the high ${ }^{3} \mathrm{He} /{ }^{4} \mathrm{He}$ reservoir is apparently not a feature preserved in the convecting upper mantle sampled by mid-ocean ridges (see Sections 3 and 4.1). Thus, the shallow mantle may not be an ideal location for the preservation of the FOZO-A and FOZO-B mantle domains. However, the less rapid convective motions of the lower mantle may make it a more suitable home for the FOZOs (Hart et al., 1992; Macpherson et al., 1998; van Keken et al., 2002; Class and Goldstein, 2005).

One mechanism for the preservation of hemisphericscale heterogeneity may be the isolation of the high ${ }^{3} \mathrm{He} /{ }^{4} \mathrm{He}$ domains in a dense boundary layer at the coremantle boundary (CMB). Seismic tomography suggests that some hotspots, like Samoa and Hawaii, may well originate as upwellings from this region of the mantle (Montelli et al., 2006), and many hotspots with high ${ }^{3} \mathrm{He} /{ }^{4} \mathrm{He}$ have been associated with velocity anomalies in the deep mantle (Courtillot et al., 2003). The postperovskite phase proposed to exist at this depth may exhibit a sufficiently large density contrast to isolate it from the overlying convecting mantle (Guignot et al., 2007), and a new seismic technique may allow detection of this phase at the base of the mantle (van der Hilst et al., 2007). Exploiting this new seismic tool, it may be possible to better resolve the spatial relationships between velocity anomalies at the $\mathrm{CMB}$ and high ${ }^{3} \mathrm{He} /{ }^{4} \mathrm{He}$ ocean islands at the earth's surface. Thus, a confluence of geochemical and geophysical observations may ultimately reveal the mechanism responsible for the longterm preservation of the hemispheric heterogeneity in the deep mantle, a feature that hinges on new observations of high ${ }^{3} \mathrm{He} /{ }^{4} \mathrm{He}$ in Samoan lavas from Ofu.

\section{Conclusions}

From this study we draw the following conclusions:

(1) New high ${ }^{3} \mathrm{He} /{ }^{4} \mathrm{He}$ ratios (19.5-33.8 times atmospheric) from Ofu island are the highest from Samoa (and the southern hemisphere), and place Samoa in the same category of high ${ }^{3} \mathrm{He} /{ }^{4} \mathrm{He}$ hotspots as Hawaii, Iceland and the Galapagos.

(2) The new Ofu data reveal that at least two distinct high ${ }^{3} \mathrm{He} /{ }^{4} \mathrm{He}$ reservoirs-one more isotopically enriched than the other-exist in the earth's mantle.

(3) The two high ${ }^{3} \mathrm{He} /{ }^{4} \mathrm{He}$ reservoirs separate in the earth's northern (FOZO-B, boreal) and southern (FOZO-A, austral) hemispheres.

(4) The trace element budgets and isotopic compositions of the new high ${ }^{3} \mathrm{He} /{ }^{4} \mathrm{He}$ samples from Samoa 
are inconsistent with derivation from recycled harzburgite. Additionally, the Samoan high ${ }^{3} \mathrm{He} /{ }^{4} \mathrm{He}$ mantle does not appear to be contaminated with rapidly cycled sediment from the Tonga subduction zone. Furthermore, the $\mathrm{Nd}$ and $\mathrm{Pb}$ isotopes of the highest ${ }^{3} \mathrm{He} /{ }^{4} \mathrm{He}$ Samoan basalts demonstrate that they were not derived from a chondritic primitive mantle.

(5) If the terrestrial ${ }^{142} \mathrm{Nd} /{ }^{144} \mathrm{Nd}$ anomaly relative to chondrites is due to the decay of ${ }^{146} \mathrm{Sm}$, the observed ${ }^{143} \mathrm{Nd} /{ }^{144} \mathrm{Nd}$ ratios in FOZO-A and FOZO$\mathrm{B}$ lavas require that they were re-enriched relative to either a non-chondritic BSE or the EDR.

(6) The high ${ }^{3} \mathrm{He} /{ }^{4} \mathrm{He}$ mantle is an ancient reservoir, and the discovery of isotopically distinct northern and southern hemisphere high ${ }^{3} \mathrm{He} /{ }^{4} \mathrm{He}$ mantle domains suggests that these regions of the mantle escaped the convective mixing and stirring that has efficiently attenuated heterogeneities in the upper mantle. This observation provides an important constraint for future dynamic and isotopic models describing the evolution of the earth's mantle.

\section{Acknowledgements}

We are indebted to D. Hilton and P. Castillo for supplying a high ${ }^{3} \mathrm{He} /{ }^{4} \mathrm{He}$ sample from Iceland for trace element analysis, and to T. Hanyu for supplying a high ${ }^{3} \mathrm{He} /{ }^{4} \mathrm{He}$ sample from Moorea. We thank W. White and C. Macpherson for helpful reviews, and R. Carlson for helpful comments and editorial handling. Discussion with F. Stuart, C. Class, A. Hofmann, N. Shimizu, A. Shaw and J. Blusztajn helped shape the thinking that went into this manuscript. We thank L. Ball for his assistance on the Neptune in the WHOI Plasma Facility, and J. Curtice for his invaluable help in the noble gas facility. Helium isotope measurements were supported by OCE 05-25864. Fa'afetai to the Malae family at Ofu's Vaoto Lodge for their hospitality during the 2004 and 2005 field seasons.

\section{Appendix A. Supplementary data}

Supplementary data associated with this article can be found, in the online version, at doi:10.1016/j. eps1.2007.09.023.

\section{References}

Abouchami, W., Galer, S.J.G., Koschinsky, A., 1999. Pb and $\mathrm{Nd}$ isotopes in NE Atlantic $\mathrm{Fe}-\mathrm{Mn}$ crusts: proxies for trace metal paleosources and paleocean circulation. Geochim. Cosmochim. Acta $63,1489-1505$.
Anderson, D.L., 1998. A model to explain the various paradoxes associated with mantle noble gas geochemistry. Proc. Natl. Acad. Sci. U. S. A. 95, 9087-9092.

Andreasen, R., Sharma, M., 2006. Solar nebula heterogeneity in pprocess samarium and neodymium isotopes. Science 314, 806-809.

Barling, J., Goldstein, S.L., 1990. Extreme isotopic variations in Heard Island lavas and the nature of mantle reservoirs. Nature 348 , $59-62$.

Boyet, M., Carlson, R.W., 2005. ${ }^{142} \mathrm{Nd}$ evidence for early (>4.53 Ga) global differentiation of the silicate earth. Science 309, 576-581.

Boyet, M., Carlson, R.W., 2006. A new geochemical model for the Earth's mantle inferred from ${ }^{146} \mathrm{Sm}-{ }^{144} \mathrm{Nd}$ systematics. Earth Planet. Sci. Lett. 250, 254-268.

Brandon, A.D., Graham, D.W., Waight, T., Gautason, B., 2007. ${ }^{186}$ Os and ${ }^{187} \mathrm{Os}$ enrichments in high- ${ }^{3} \mathrm{He} /{ }^{4} \mathrm{He}$ sources in the Earth's deep mantle: evidence from Icelandic picrites. Geochim. Cosmochim. Acta 71, 4570-4591.

Carlson, R.W., Boyet, M., Horan, M., 2007. Chondrite barium, neodymium, and samarium isotopic heterogeneity and early earth differentiation. Science 316, 1175-1178.

Castillo, P., 1988. The Dupal anomaly as a trace of the upwelling lower mantle. Nature 336, 667-670.

Castillo, P.R., Scarsi, P., Craig, H., 2007. He, Sr, Nd and Pb isotopic constraints on the origin of the Marquesas and other linear volcanic chains. Chem. Geol. 240, 205-221.

Class, C., Goldstein, S.L., 2005. Evolution of helium isotopes in the Earth's mantle. Nature 436, 1107-1112.

Courtillot, V., Davaille, A., Besse, J., Stock, J., 2003. Three distinct types of hotspots in the Earth's mantle. Earth Planet. Sci. Lett. 205, 295-308.

Doucelance, R., Escrig, S., Moreira, M., Gariépy, C., Kurz, M.D., 2003. $\mathrm{Pb}-\mathrm{Sr}-\mathrm{He}$ isotope and trace element geochemistry of the Cape Verde Archipelago. Geochim. Cosmochim. Acta 67, 3717-3733.

Eisele, J., Sharma, M., Galer, S.J.G., Blichert-Toft, J., Devey, C.W., Hofmann, A.W., 2002. The role of sediment recycling in EM-1 inferred from $\mathrm{Os}, \mathrm{Pb}, \mathrm{Hf}, \mathrm{Nd}$, Sr isotope and trace element systematics of the Pitcairn hotspot. Earth Planet. Sci. Lett. 196, 197-212.

Ellam, R.M., Stuart, F.M., 2004. Coherent He-Sr-Nd isotope trends in high ${ }^{3} \mathrm{He} /{ }^{4} \mathrm{He}$ basalts: implications for a common reservoir, mantle heterogeneity and convection. Earth Planet. Sci. Lett. 228, 511-523.

Farley, K.A., 1995. Rapid cycling of subducted sediments into the Samoan mantle plume. Geology 23, 531-534.

Farley, K.A., Natland, J.H., Craig, H., 1992. Binary mixing of enriched and undegassed (primitive?) mantle components ( $\mathrm{He}, \mathrm{Sr}, \mathrm{Nd}, \mathrm{Pb}$ ) in Samoan lavas. Earth Planet. Sci. Lett. 111, 183-199.

Farley, K.A., Basu, A.R., Craig, H., 1993. He, Sr and Nd isotopic variations in lavas from Juan Fernandez Archipelago, SE Pacific. Contrib. Mineral. Petrol. 115, 75-87.

Galer, S.J.G., 1986. Chemical and isotopic studies of crust-mantle differentiation and the generation of mantle heterogeneity. PhD, University of Cambridge (unpublished).

Gerlach, D.C., Hart, S.R., Morales, V.W.J., Palacios, C., 1986. Mantle heterogeneity beneath the Nazca plate: San Felix and Juan Fernandez islands. Nature 322, 165-169.

Graham, D.W., 2002. Noble gas isotope geochemistry of mid-ocean ridge and ocean island basalts; characterization of mantle source reservoirs. In: Porcelli, D., Ballentine, C.J., Wieler, R. (Eds.), Noble Gases in Geochemistry and Cosmochemistry. Reviews in Mineralogy and Geochemistry, vol. 47, pp. 247-318.

Graham, D.W., Lupton, J., Alberède, F., Condomines, M., 1990. Extreme temporal homogeneity of helium isotopes at Piton de la Fournaise, Reunion Island. Nature 347, 545-548. 
Graham, D.W., Larsen, L.M., Hanan, B.B., Storey, M., Pedersen, A.K., Lupton, J.E., 1998. Helium isotope composition of the early Iceland mantle plume inferred from the Tertiary picrites of West Greenland. Earth Planet. Sci. Lett. 160, 241-255.

Graham, D.W., Reid, M.R., Jordan, B.T., Grunder, A.L., Leeman, W.P., Lupton, J.E., 2006. A helium isotope perspective on mantle sources for basaltic volcanism in the northwestern US. Eos Trans., vol. 87. American Geophysical Union. Abstract V43D-02.

Guignot, N., Andrault, D., Morard, G., Bolfan-Casanova, N., Mezouar, M., 2007. Thermoelastic properties of post-perovskite phase $\mathrm{MgSiO}_{3}$ determined experimentally at core-mantle boundary P-T conditions. Earth Planet. Sci. Lett. 256, 162-168.

Hanan, B.B., Graham, D.W., 1996. Lead and helium isotope evidence from oceanic basalts for a common deep source of mantle plumes. Science 272, 991-995.

Hanyu, T., Kaneoka, I., 1997. The uniform and low ${ }^{3} \mathrm{He} /{ }^{4} \mathrm{He}$ ratios of HIMU basalts as evidence for their origin as recycled materials. Nature 390, 273-276.

Hart, S.R., 1984. A large-scale isotope anomaly in the Southern Hemisphere mantle. Nature 309, 753-757.

Hart, S., 1988. Heterogeneous mantle domains: signatures, genesis and mixing chronologies. Earth Planet. Sci. Lett. 90, 273-296.

Hart, S.R., Blusztajn, J., 2006. Age and geochemistry of the mafic sills, ODP site 1276, Newfoundland margin. Chem. Geol. 235, 222-237.

Hart, S.R., Hauri, E.H., Oschmann, L.A., Whitehead, J.A., 1992. Mantle plumes and entrainment: isotopic evidence. Science 256, 517-520.

Hart, S.R., Coetzee, M., Workman, R.K., Blusztajn, J., Johnson, K.T.M., Sinton, J.M., Steinberger, B., Hawkins, J.W., 2004. Genesis of the Western Samoa seamount province: age, geochemical fingerprint and tectonics. Earth Planet. Sci. Lett. 227, 37-56.

Hauri, E.H., Hart, S.R., 1993. Re-Os isotope systematics of HIMU and EMII oceanic island basalts from the south Pacific Ocean. Earth Planet. Sci. Lett. 114, 353-371.

Hauri, E.H., Shimizu, N., Dieu, J.J., Hart, S.R., 1993. Evidence for hotspot-related carbonatite metasomatism in the oceanic upper mantle. Nature 365, 221-227.

Heber, V.S., Brooker, R.A., Kelley, S.P., Wood, B.J., 2007. Crystalmelt partitioning of noble gases (helium, neon, argon, krypton, and xenon) for olivine and clinopyroxene. Geochim. Cosmochim. Acta 71, 1041-1061.

Hémond, C., Devey, C.W., Chauvel, C., 1994. Source compositions and melting processes in Society and Austral plumes (South Pacific Ocean): element and isotope ( $\mathrm{Sr}, \mathrm{Nd}, \mathrm{Pb}, \mathrm{Th}$ ) geochemistry. Chem. Geol. 115, 7-45.

Hidaka, H., Ohta, Y., Yoneda, S., 2003. Nucleosynthetic components of the early solar system inferred from Ba isotopic compositions in carbonaceous chondrites. Earth Planet. Sci. Lett. 214, 455-466.

Hilton, D.R., Barling, J., Wheller, G.E., 1995. Effect of shallow-level contamination on the helium isotope systematics of ocean-island lavas. Nature 373, 330-333.

Hilton, D.R., Grönvold, K., Macpherson, C.G., Castillo, P.R., 1999. Extreme ${ }^{3} \mathrm{He} /{ }^{4} \mathrm{He}$ ratios in northwest Iceland: constraining the common component in mantle plumes. Earth Planet. Sci. Lett. 173, 53-60.

Hofmann, A.W., White, W.M., 1983. Ba, Rb and Cs in the Earth's mantle. Z. Naturforsch 38 (a), 256-266.

Jackson, M.J., Hart, S.R., Koppers, A.A.P., Staudigel, H., Konter, J., Blusztajn, J., Kurz, M.D., Russell, J.A., 2007. Evidence for the return of subducted continental crust in Samoan lavas. Nature 448, 684-697.

Kelemen, P.B., Yogodzinski, G.M., Scholl, D.W., 2004. Alongstrike variation in lavas of the Aleutian island arc: implications for the genesis of high $\mathrm{Mg} \#$ andesite and the continental crust. In: Eiler, J.
(Ed.), Inside the Subduction Factory. AGU Geophysical Monograph, vol. 138, pp. 223-276.

Koppers, A.A.P., Russell, J.A., Jackson, M.G., Konter, J., Staudigel, H., Hart, S.R., submitted for publication. Samoa reinstated as a primary hotspot trail, Geology.

Kurz, M.D., Geist, D.J., 1999. Dynamics of the Galapagos hotspot from helium isotope geochemistry. Geochim. Cosmochim. Acta 63, 4139-4156.

Kurz, M.D., Jenkins, W.J., Hart, S.R., 1982. Helium isotopic systematics of oceanic islands and mantle heterogeneity. Nature 297, 43-47.

Kurz, M.D., Jenkins, W.J., Hart, S.R., Clague, D., 1983. Helium isotopic variations in volcanic rocks from Loihi Seamount and the Island of Hawaii. Earth Planet. Sci. Lett. 66, 388-406.

Kurz, M.D., Le Roex, A.P., Dick, H.J.B., 1998. Isotope geochemistry of the oceanic mantle near Bouvet triple junction. Geochim. Cosmochim. Acta 62, 841-852.

Kurz, M.D., Curtice, J.C., Lott III, D.E., Solow, A., 2004. Rapid helium isotopic variability in Mauna Kea shield lavas from the Hawaiian Scientific Drilling Project. Geochem., Geophys., Geosyst. 4, Q04G14. doi:10.1029/2002GC000439.

Macpherson, C.G., Hilton, D.R., Sinton, J.M., Poreda, R.J., Craig, H., 1998. High ${ }^{3} \mathrm{He} /{ }^{4} \mathrm{He}$ ratios in Manus backarc basin: implications for mantle mixing and the origin of plume in the western Pacific Ocean. Geology 26, 1007-1010.

Madureira, P., Moreira, M., Mata, J., Allègre, C.J., 2005. Primitive neon isotopes in Terceira Island (Azores archipelago). Earth Planet. Sci. Lett. 233, 429-440.

McDonough, W.F., Sun, S.S., 1995. The composition of the earth. Chem. Geol. 120, 223-253.

Montelli, R., Nolet, G., Dahlen, F.A., Masters, G., 2006. A catalogue of deep mantle plumes: new results from finite-frequency tomography. Geochem., Geophys., Geosystem 7, Q11007. doi:10.1029/ 2006GC001248.

Moreira, M., Allègre, C.J., 2004. Helium isotopes on the Macdonald seamount (Austral chain): constraints on the origin of the superswell. C. R. Géosci. 336, 983-990.

Moreira, M., Doucelance, R., Kurz, M.D., Dupré, B., Allègre, C.J., 1999. Helium and lead isotope geochemistry of the Azores Archipelago. Earth Planet. Sci. Lett. 169, 189-205.

Natland, J.H., 1980. The progression of volcanism in the Samoan linear volcanic chain. Am. J. Sci. 280-A, 709-735.

O'Nions, R.K., Hamilton, P.J., Evensen, N.M., 1977. Variations in ${ }^{143} \mathrm{Nd} /{ }^{144} \mathrm{Nd}$ and ${ }^{87} \mathrm{Sr} /{ }^{86} \mathrm{Sr}$ ratios in oceanic basalts. Earth Planet. Sci. Lett. 34, 13-22.

Parman, S.W., Kurz, M.D., Hart, S.R., Grove, T.L., 2005. Helium solubility in olivine and implications for high ${ }^{3} \mathrm{He} /{ }^{4} \mathrm{He}$ in ocean island basalts. Nature 437, 1140-1143.

Plank, T., Langmuir, C., 1998. The chemical composition of subducting sediment and its consequences for the crust and mantle. Chem. Geol. 145, 325-394.

Poreda, R.J., Craig, H., 1992. He and Sr isotopes in the Lau Basin mantle: depleted and primitive mantle components. Earth Planet. Sci. Lett. 113, 487-493.

Poreda, R.J., Farley, K.A., 1992. Rare gases in Samoan xenoliths. Earth Planet. Sci. Lett. 113, 129-144.

Ranen, M.C., Jacobsen, S.B., 2006. Barium isotopes in chondritic meterorites: implications for planetary reservoir models. Science 314, 809-812.

Rudnick, R.L., Gao, S., 2003. Composition of the continental crust. In: Rudnick, R.L. (Ed.), Treatise on Geochemistry. The Crust, vol. 3. Permagon, New York, pp. 1-64. 
Saal, A.E., Kurz, M.D., Hart, S.R., Blusztajn, J.S., Blichert-Toft, J., Liang, Y., Geist, D.J., 2007. The role of lithospheric gabbros on the composition of Galapagos lavas. Earth Planet. Sci. Lett. 257, 391-406.

Scarsi, P., Craig, H., 1996. Helium isotope ratios in Ethiopian Rift basalts. Earth Planet. Sci. Lett. 144, 505-516.

Staudigel, H., Zindler, A., Hart, S.R., Leslie, T., Chen, C.-Y., Clague, D., 1984. The isotopic systematics of a juvenile intraplate volcano: $\mathrm{Pb}, \mathrm{Nd}$ and $\mathrm{Sr}$ isotope ratios of basalts from Loihi Seamount, Hawaii. Earth Planet. Sci. Lett. 69, 13-29.

Stuart, F.M., Lass-Evans, S., Fitton, J.G., Ellam, R.M., 2003. High ${ }^{3} \mathrm{He} /{ }^{4} \mathrm{He}$ ratios in picritic basalts from Baffin Island and the role of a mixed reservoir in mantle plumes. Nature 424, 57-59.

Su, Y., 1986. Global MORB chemistry compilation at the segment scale. PhD., Columbia University (available at http://petdb.ldeo. columbia.edu/documentation/morbcompilation/).

Taras, B.D., Hart, S.R., 1987. Geochemical evolution of the New England seamount chain: isotopic and trace element constraints. Chem. Geol. 64, 35-54.

Todt, W., Cliff, R.A., Hanser, A., Hofmann, A.W., 1996. Evaluation of a ${ }^{202} \mathrm{~Pb}-{ }^{205} \mathrm{~Pb}$ double spike for high-precision lead isotope analysis. In: Basu, A., Hart, S.R. (Eds.), Earth Processes: Reading the Isotopic Code. AGU Geophysical Monograph, vol. 95, pp. 429-437.

Turner, S., Hawkesworth, C., Rogers, N., King, P., 1997. U-Th disequilibria and ocean island basalt generation in the Azores. Chem. Geol. 139, 145-164.

Valbracht, P.J., Staudacher, T., Malahoff, A., Allègre, C.J., 1997. Noble gas systematics of deep rift zone glasses from Loihi Seamount, Hawaii. Earth Planet. Sci. Lett. 150, 399-411. van der Hilst, R.D., de Hoop, M.V., Wang, P., Shim, S.-H., Ma, P., Tenorio, L., 2007. Seismostratigraphy and thermal structure of Earth's core-mantle boundary region. Science 315, 1813-1817.

van Keken, P.E., Hauri, E.H., Ballentine, C.J., 2002. Mantle mixing: the generation, preservation and destruction of chemical heterogeneity. Annu. Rev. Earth Planet. Sci. 30, 493-525.

Wombacher, F., Becker, H., 2007. Barium isotope compositions of chondrites revisited. 17th Annual V.M. Goldschmidt Conference, Cologne, Germany, p. A1125.

White, W.M., 2005. Helium not in store. Nature 436, 1095-1096.

White, W.M., Hofmann, A.W., 1982. Sr and $\mathrm{Nd}$ isotope geochemistry of oceanic basalts and mantle evolution. Nature 296, 821-825.

Wright, E., White, W.M., 1987. The origin of Samoa: new evidence from $\mathrm{Sr}, \mathrm{Nd}$ and $\mathrm{Pb}$ isotopes. Earth Planet. Sci. Lett. 82, 151-162.

Woodhead, J.D., 1996. Extreme HIMU in an oceanic setting: the geochemistry of Mangaia Island (Polynesia), and temporal evolution of the Cook-Austral hotspot. J. Volcanol. Geotherm. Res. 72, 1-19.

Workman, R.K., Hart, S.R., 2005. Major and trace element composition of the depleted MORB mantle (DMM). Earth Planet. Sci. Lett. 231, $53-72$.

Workman, R.K., Hart, S.R., Jackson, M.G., Regelous, M., Farley, K.A., Blusztajn, J., Kurz, J., Staudigel, H., 2004. Recycled metasomatized lithosphere as the origin of the Enriched Mantle II (EM2) endmember: evidence from the Samoan Volcanic Chain. Geochem., Geophys., Geosystem 5, Q04008. doi:10.1029/2003GC000623.

Zindler, A., Hart, S.R., 1986. Chemical geodynamics. Annu. Rev. Earth Planet. Sci. 14, 493-571. 

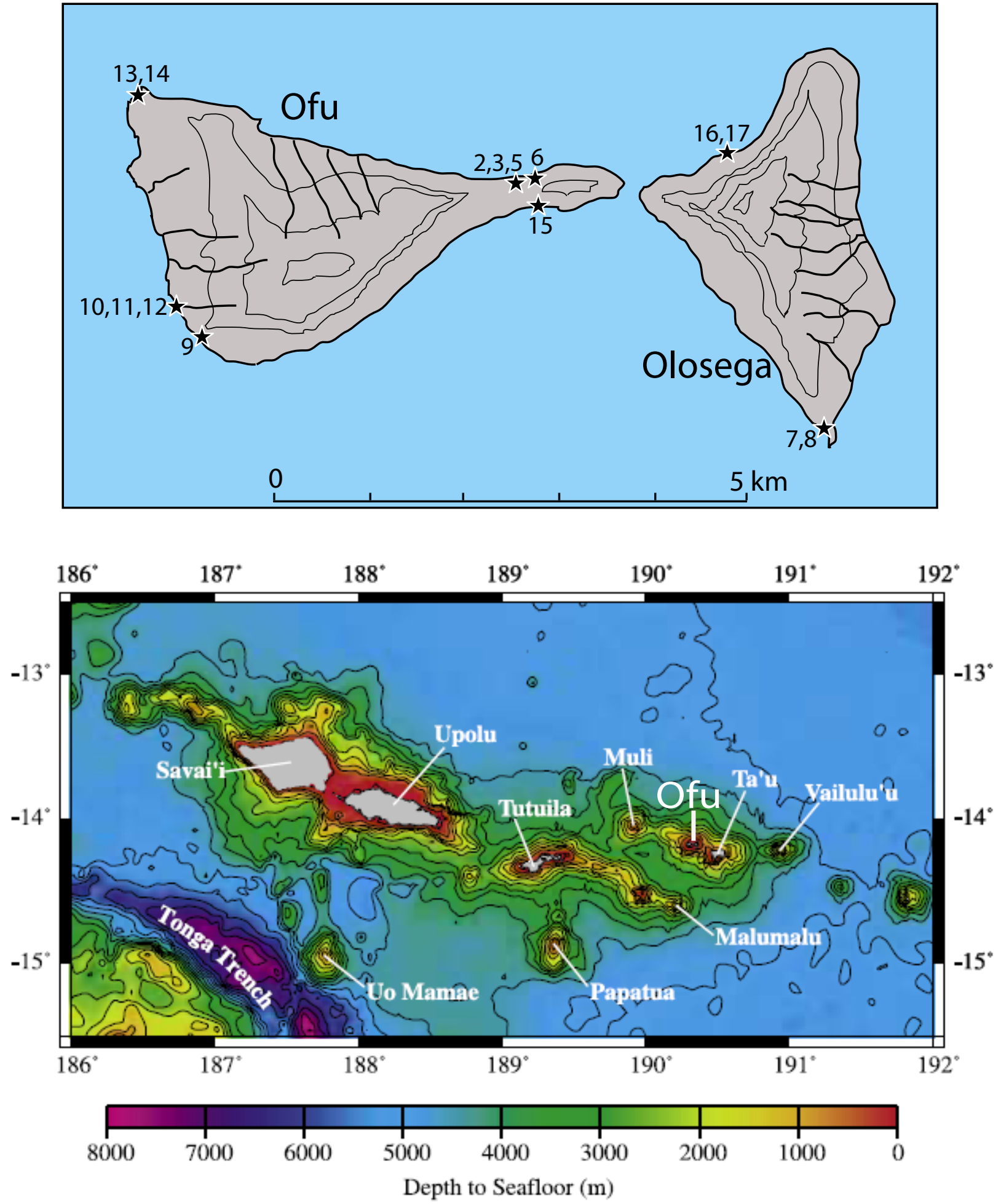

Supplementary Material Fig. 1. Upper panel: Location map for samples taken from Ofu and Olosega islands that are reported in this study. Samples were taken from the major geologic formations recorded by Stice and McCoy (1968). Lower Panel: Ofu Island relative to the subaerial islands (Savai ${ }^{i}$, Upolu, Tutuila and Ta'u) and submarine volcanoes (Muli, Malumalu and Vailulu'u) of the Eastern volcanic province (map from Workman et al. (2004)). Papatua and Uo Mamae are isolated, "off-axis" seamounts. Note Samoa's proximity to the northern termination of the Tonga arc/trench system. 

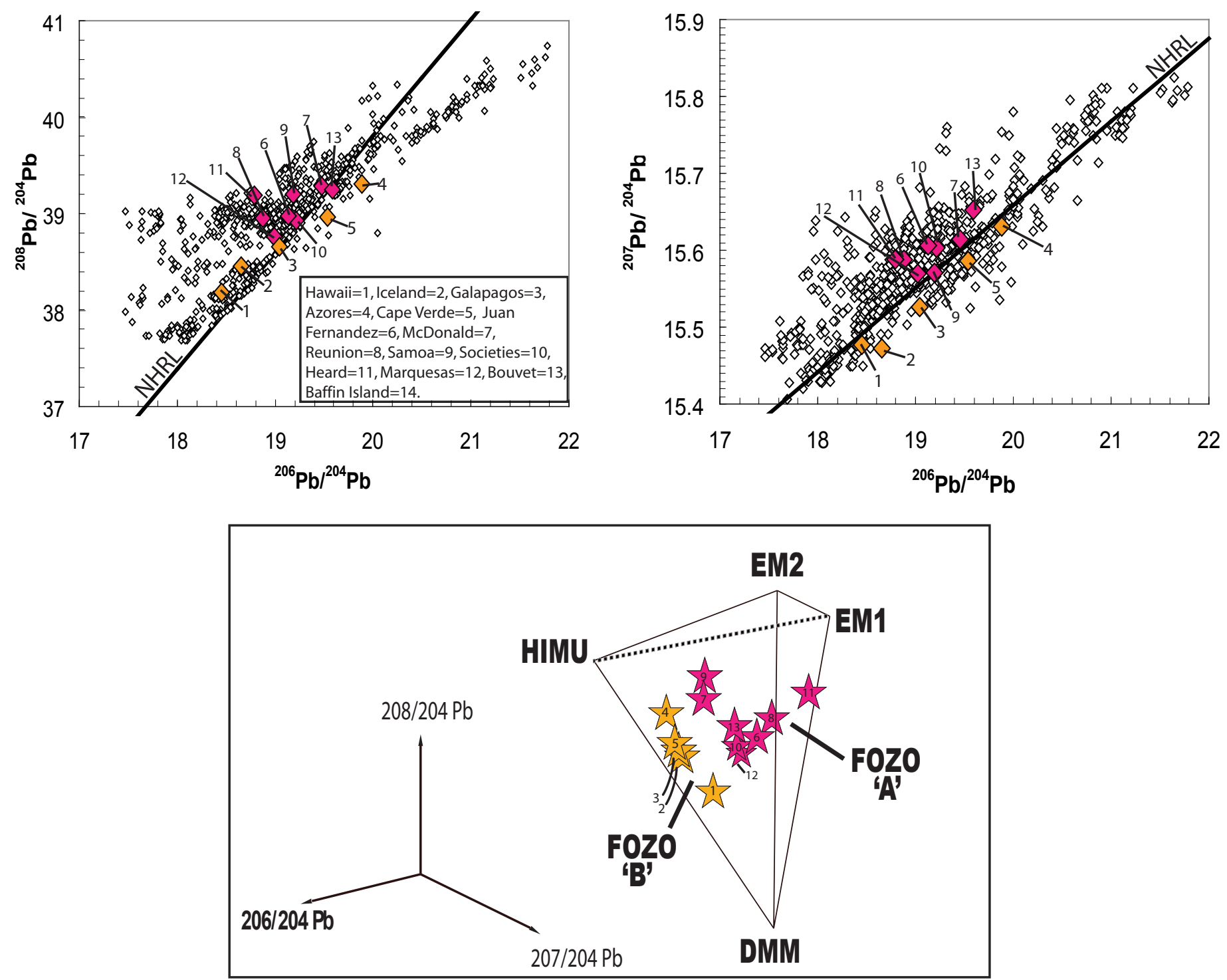

Supplementary Material Fig. 2. The separation of FOZO-A and FOZO-B in Pb-isotope space. Top panels: In two dimensional $\mathrm{Pb}$-isotope space $\left({ }^{208} \mathrm{~Pb} /{ }^{204} \mathrm{~Pb}\right.$ vs. ${ }^{206} \mathrm{~Pb} /{ }^{204} \mathrm{~Pb}$ and ${ }^{207} \mathrm{~Pb} /{ }^{204} \mathrm{~Pb}$ vs ${ }^{206} \mathrm{~Pb} /{ }^{204} \mathrm{~Pb}$ isotope spaces), the two FOZOs can be separated by a line. However, the Northern Hemisphere Reference Line (NHRL) from Hart (1984) does not appear to divide the two FOZO's in ${ }^{208} \mathrm{~Pb} /{ }^{204} \mathrm{~Pb}-{ }^{206} \mathrm{~Pb} /{ }^{204} \mathrm{~Pb}$ space, but does divide them in ${ }^{207} \mathrm{~Pb} /{ }^{204} \mathrm{~Pb}-{ }^{206} \mathrm{~Pb} /{ }^{204} \mathrm{~Pb}$ space. Open black diamonds are global OIB data. Lower panel: FOZO-A and FOZO-B separate in 3D Pb-isotope space, indicating that $\mathrm{Pb}$ isotopes are consistent with the hemispheric separation of the two high ${ }^{3} \mathrm{He} /{ }^{4} \mathrm{He}$ reservoirs. Pb-isotope data used to define FOZO-A and FOZO-B are found in Table 2. 


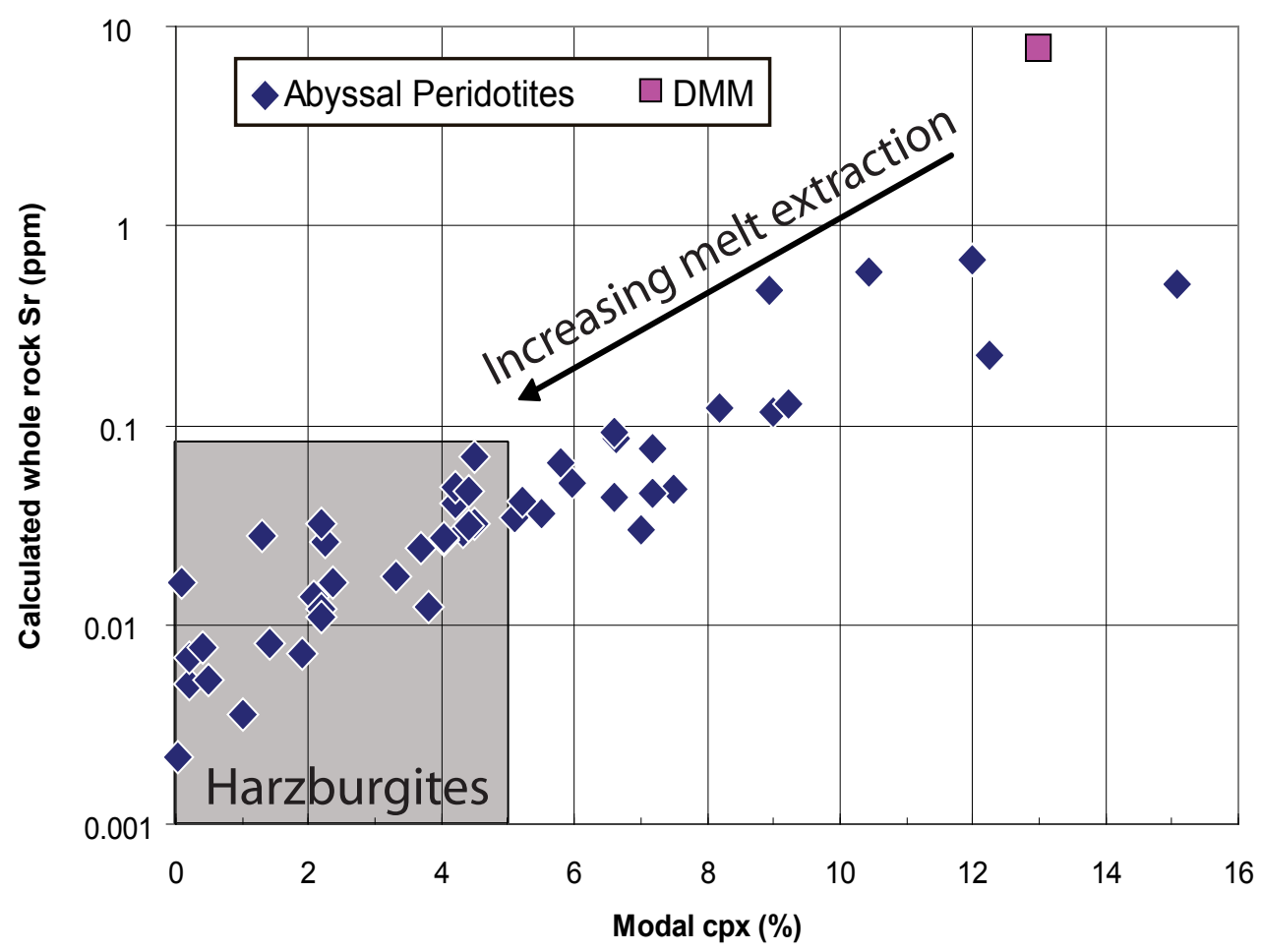

Supplementary Material Fig. 3. Modal abundance of cpx compared to reconstructed whole-rock Sr concentrations in abyssal peridoties, a proxy for recycled, depleted, oceanic upper mantle lithosphere. Sr concentrations in abyssal peridotites diminish rapidly with small reductions in cpx modal abundance, a result of melt extraction from DMM in a fractional melting regime. Harzburgites and other cpx-poor lithologies that are produced in the mantle lithosphere at mid-ocean ridges are extremely trace element depleted. These peridotites may not be good candidates for a source that generates the enriched trace-element budgets observed in Ofu lavas. The abyssal peridotite compilation accompanies Workman and Hart (2005), and the estimate for the $\mathrm{Sr}$ concentration in DMM concentrations is from the same source. Samples with modal plagioclase have been excluded. 


\section{References}

Hart, S.R., 1984. A large-scale isotope anomaly in the Southern Hemisphere mantle. Nature 309, 753-757.

Stice, G.D., McCoy, F.W., 1968. The geology of the Manu'u Islands, Samoa. Pacific. Science 22, 427-457.

Workman, R.K., Hart, S.R., 2005. Major and trace element composition of the depleted MORB mantle (DMM). Earth Planet. Sci. Lett. 231, 53-72. 